\title{
Sophisticated Shakespeare: James Toovey and the Morgan Library's "Sidney" First Folio ${ }^{1}$
}

\author{
Germaine Warkentin and Peter Hoare
}

$\mathrm{F}$ OR the past century the first collected edition of the plays of Shakespeare, issued in folio in 1623 , has come close to defining the value of a fine volume. "The book enjoys almost totemic status among book collectors and the legions of the Bard's devotees," writes Werner Gundersheimer, "and like a ritual object, it has been allowed to exist within an

1. We would like to thank the following colleagues for assistance of various kinds in tracing the story of the Morgan First Folio; any errors and omissions are entirely our responsibility. Our first and most important debt is to our friend Nicholas Pickwoad. Anthony James West acted as external reader for PBSA, and we are grateful for his comments. In addition we would like to thank (some in their official capacities): Anna Lou Ashby and John Bidwell (The Morgan Library), Nicolas Barker, Robert Bearman (Shakespeare Birthplace Trust Records Office), Sister Mary Bernard and Sister Jane Mary (Society of the Precious Blood, Burnham Abbey), Joseph L. Black, Peter Blayney, Michael Brennan, Alexandra

Germaine Warkentin (VC 205, Victoria College, Toronto, Canada, $\mathrm{M}_{5} \mathrm{~S}_{1} \mathrm{~K}_{7}$; g.warkentin@utoronto.ca), Professor Emeritus of English, University of Toronto, has published widely on Renaissance and early Canadian writing, especially on Petrarch, Spenser, Philip Sidney, and Canadian exploration literature. She is Director of the Penshurst Library project and is editing for the Champlain Society the writings of the explorer and adventurer Pierre-Esprit Radisson. Her edition of "The Educated Imagination" and Other Writings on Critical Theory, 1933-1963 (forthcoming 2006) will appear as volume 21 of the Collected Works of Northrop Frye.

Peter Hoare (21 Oundle Drive, Wollaton Park, Nottingham NG8 $1 B N$, England; p.hoare@virgin.net), formerly University Librarian at the University of Nottingham, works as a freelance librarian specializing in historic libraries and rare books and as a library historian. He is general editor of the Cambridge History of Libraries in Britain and Ireland (forthcoming 2006).

$$
\text { PBSA 100:3 (2006): 313-56 }
$$


aura of mystery, if not actual mystification." ${ }^{2}$ The famous folio is not, by the standards of early modern editions, a book of any real rarity; about 228 copies are known to exist. ${ }^{3}$ As W. W. Greg observed in 1903, "the known value of the volume has caused a number of very inferior copies to be preserved which would else have found their way into the waste paper basket." ${ }^{4}$ But Shakespeare's great name, the ambitions of such collectors as Henry Clay Folger, who assembled 82 copies, as well as numerous fragments, for his library in Washington, ${ }^{5}$ and particularly the bibliographical interest of the volume, continue to make it a treasure much coveted. ${ }^{6}$ Despite vagaries in the market, the average price of the four

Buchanan, Donald Farren, Gillian Fenwick, Christine Ferdinand (Magdalen College, Oxford), Mirjam Foot (British Library and University College, London), Martha Kurtz, Dennis Landis (John Carter Brown Library), Richard Landon and Philip Oldfield (Thomas Fisher Library, University of Toronto), John Goldfinch and Giles Mandelbrote (British Library), Richard Linenthal (Bernard Quaritch Ltd.), Keith Manley (Institute of Historical Research), Sally Mason (Centre for Buckinghamshire Studies), Janet McMullin (Christ Church, Oxford), Paul Nelles, Mark Nicholls (St. John's College, Cambridge), Jill Palmer (Dorney Court), J. Fernando Peña (Grolier Club), James Raven, David Shaw, Julia Walworth (Merton College, Oxford), John Warkentin, Philip Weimerskirch, Georgianna Ziegler (Folger Shakespeare Library), and Rivkah Zim; at the Bodleian Library, Michael Turner and Greg Colley, as well as William Hodge and his assistants in Duke Humfrey.

2. Peter W.M. Blayney, The First Folio of Shakespeare (Washington: Folger Library Publications, 1991), "Foreword," by Werner Gundersheimer, [vii].

3. There is no really precise figure; for example it depends on whether one is counting complete First Folios or made-up copies. See Anthony James West, The Shakespeare First Folio: The History of the Book, vol. 2: A New World Wide Census of First Folios (Oxford: Oxford Univ. Press, 2003; hereafter $W e s t S F F_{2}$ ), passim. West's numeration of copies is referred to henceforth as, e.g., "West 217." Copies in the 1902 census by Sidney Lee (see note 16) are referred to as, e.g., "Lee 37."

4. W. W. Greg, "The Bibliographical History of the First Folio," The Library, n.s., 4 (1903): 266.

5. West lists 82 Folger copies in his main sequence (West $S F F_{2}, 149-99$, and see also 74-5). Peter Blayney is cautious about defining the precise number of Folger First Folios; only 13 are complete, and there are many made-up or incomplete copies, in addition to fragments. He considers Charlton Hinman's "over eighty" to be realistic; see Blayney, The First Folio of Shakespeare, 45-6.

6. For the historic escalation in price of the First Folio over the past century and a half, see Anthony James West, The Shakespeare First Folio: The History of the Book, vol. 1: An Account of the First Folio Based on its Sales and Prices, 1623-2000 
First Folios sold in the 1990 s was around $£_{150,000}{ }^{7}$ and the latest high price mentioned by Anthony James West is for Abel Berland's copy (West 145, Lee 75), which was sold at Christie's on 8 October 2001 for $\$ 5,600$, 000 plus buyer's premium (10 percent) and sales tax. ${ }^{8}$ More recently Oriel College, Oxford, sold its copy (West 33, Lee 49) to Sir Paul Getty in March 2003, shortly before his death, for over three million pounds. ${ }^{9}$ The fine copy from Dr. Williams's library sold at Sotheby's on 13 July 2006 for $£ 2.5$ million, before buyer's premium of 12 percent. It was bought by Simon Finch, a London dealer, on behalf of an unnamed client.

In 1899 the financier J. Pierpont Morgan, motivated by the collector's lust and well prepared to pay top dollar for the period, purchased from the London bookseller C. J. Toovey a collection of Aldines, fine bindings and high spots, including a First Folio (today PML 5122; West 171, Lee 37 ) to add to the remarkable library he was accumulating. ${ }^{10}$ These books had been brought together by C.J.'s late father, the noted Piccadilly bookseller James Toovey, and in 1901 Morgan had the collection as he had purchased it described in a luxurious catalogue. ${ }^{11}$ Fine as all these volumes were, the 1623 Folio boasted a special attraction: its binding bears the armorial book-stamp of Robert Sidney of Penshurst Place (1563-1626), first earl of Leicester of the second creation, younger brother of the poet and soldier Sir Philip Sidney (1554-86) and grandfather of the political martyr Algernon Sidney (1622-83), alleged Rye House plotter and theorist of classical republicanism (Illus. 1). Thus not only was the book a Shakespeare First Folio, but it was also associated with a family of great renown in English literature and history. Victorian readers were deeply interested not only in the famous story of the heroic death of Sir Philip as the result of a wound suffered on the battlefield at

(Oxford: Oxford Univ. Press, 2001, hereafter $W e s t S F F_{1}$ ). See particularly figure 1.4 (61) for the rise in average price by decade, 1860s-1970s, and figure 1.5 (65), "First Folios and Gutenberg Bibles: Prices, 1793-1978."

7. West $S F F_{1}, 52$.

8. West $S F_{2}, 204$ and 247-50. Christie's did not identify the purchaser, and West describes the copy as "In transit."

9. West $S F F_{2}$, 118-21.

10. The sale was reported by the Times on 14 July 1899,6 .

11. Catalogue of a Collection of Books Formed by James Toovey Principally from the Library of the Earl of Gosford: The Property of J. Pierpont Morgan (New York: privately printed, 1901). Henceforth Morgan 1901. 


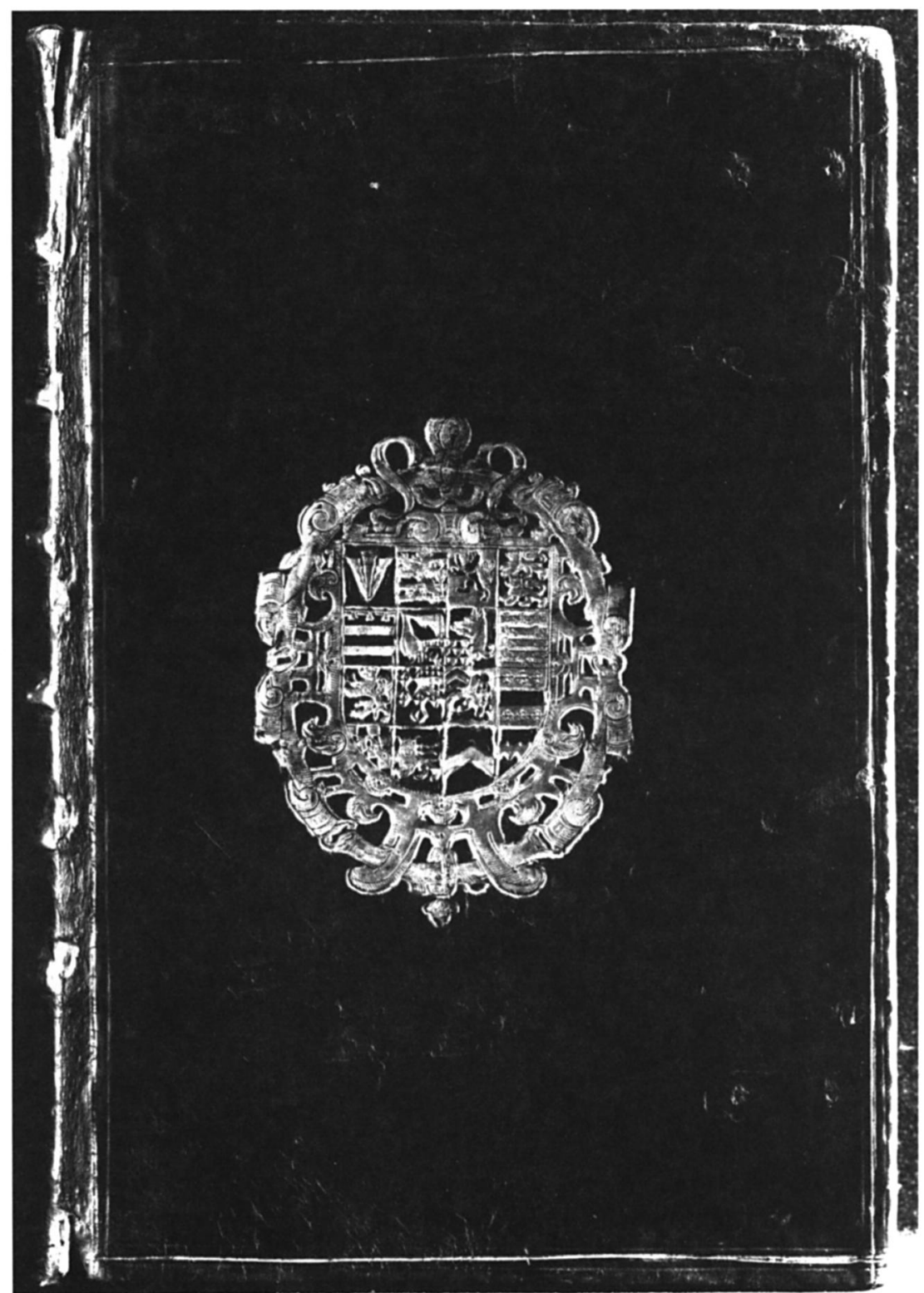

Illus. 1: Front cover of Morgan "Sidney" First Folio (The Pierpont Morgan Library, New York, PML 5122) 
Zutphen, but in the penalty for alleged high treason imposed by Judge Jeffreys on Philip's grand-nephew Algernon, the drama of which prompted the youthful G. K. Chesterton to heroic verse:

Yonder looms the block and headsman, yonder swell the rabble's cries,

And I go from hence to seek it through the starred eternities. ${ }^{12}$

Unfortunately, however, the so-called Sidney First Folio, reportedly among James Toovey's greatest treasures and highly prized by J. P. Morgan, falls somewhat short of the family legend. If the earls of Leicester in the seventeenth century possessed a First Folio, it is not listed as such in their library catalogue, which clearly indicates that they possessed the Second Folio: the entry there reads "Shakespeares Playes in fol. 1632." And indeed, by 1906 it had been revealed that the "Sidney" binding was quite unrelated to the text-block it covered; the volume was a remboitage. That is, someone had transferred the book

from its own binding to another more elegant, more nearly contemporary, more appropriate - anyway, more desirable; or...into a superior binding of a text more interesting or valuable than the one for which it was made. This often involves a new LETTERING-PIECE (the leather label); but even so, if it has been skilfully executed, it is sometimes difficult to detect.

That is the definition of this kind of sophistication, or perfecting, given in John Carter's $A B C$ for Book Collectors. ${ }^{14}$

The perfecting of copies of the First Folio began in the last half of the eighteenth century. Peter Blayney attributes the early stages of this "breaking up and making up" less to the book collector's desire for a copy in mint condition than to the scholar's need, before type facsimiles and the use of photography, for the complete 1623 text. The motive for such sophistication, he observes, "was usually honest: to create an $a p$ pearance of completeness, but not necessarily an illusion." ${ }^{15}$ However, by

12. "Algernon Sydney," in Aidan Mackey, ed., The Collected Works of G. K. Chesterton (San Francisco: Ignatius Press, 1994), 10:23-4.

13. Maidstone: Centre for Kentish Studies, De L'Isle Manuscripts, $U_{1475} Z_{45} / 2$, f.175 $5^{v}$, third entry. Lee could not have known this catalogue, to which attention was drawn by Germaine Warkentin, "Ins and Outs of the Sidney Family Library" (Times Literary Supplement, 6 December 1985), 1394 and 1411.

14. John Carter, $A n A B C$ for Book Collectors, 8th ed., with corrections, additions, and an introduction by Nicolas Barker (New Castle, Delaware: Oak Knoll Books, and [London]: British Library, 2004), 187. See also the recent "Sophistication," The Book Collector 55, no. 2 (2006): 11-27.

15. Blayney, The First Folio of Shakespeare, 36. See also $\mathrm{West}_{\mathrm{SFF}}, \mathrm{23}^{-4}$. 
the end of the nineteenth century booksellers "selling on" a scholar's working copy of this kind could advertise it as "complete" with few questions asked. They regularly assembled the available stock of fragments and broken-up books ("hospital copies" they were called) into new "complete" volumes. In such a setting, the making of a remboitage is almost to be expected, and the one passed off on Morgan would have surprised few in the trade at the time.

The difficulty of detecting a remboitage once made, however, is perhaps why it was not until 11 January 1920 that Belle da Costa Greene, Morgan's formidable librarian, wrote to Sidney Lee, author of the first comprehensive census (1902) of the Shakespeare First Folios, ${ }^{16}$ as follows: I have been going into the matter of our First Folio Shakespeare from the Toovey collection, and understand from M. Seymour de Ricci that you consider that the volume was put into the (present) covers bearing the Leicester arms sometime after Mr. Toovey acquired it. M. de Ricci has very carefully collated this book with the description given in the Hartley sale catalogue with which it seems to agree even to the description of the label on the back of the binding, but no mention is made in this catalogue description of any arms on the covers.

We should much like to know if Mr. Davis (who I understand is your informant) has any proof that the mill boards in his possession are from this (Leicester) binding. If a transfer has been made it is very cleverly done as it is not at all evident. ${ }^{17}$

Da Costa Greene's irritation may be surmised, especially since Morgan regarded the volume in question as the most important of the three First Folios he then possessed. ${ }^{18}$ She and her employer seem to have only just learned of the situation, though Seymour de Ricci had been in contact with her for many years, ${ }^{19}$ and de Ricci cannot have been un-

16. Sidney Lee, Shakespeare's Comedies, Histories, E Tragedies; A Supplement to the Reproduction in Facsimile of the First Folio Edition, 1623, from the Chatsworth Copy in the Possession of the Duke of Devonshire; Containing a Census of Extant Copies, with Some Account of Their History and Condition (Oxford: Clarendon, 1902); hereafter Lee, Census.

17. Belle da Costa Greene to Sir Sidney Lee, 11 January 1920, Morgan Library (Archives; "Dealers' Files"). She was evidently confused about the origin of the mill boards.

18. J. S. Morgan (nephew of J. Pierpont) to Sidney Lee, 9 April 1902, Shakespeare Birthplace Trust Record Office (hereafter SBTRO), ER 86/6/1 (in envelope 1). One of the Morgan First Folios (West 119) was later de-accessioned; see West $\mathrm{SFF}_{2}, 226$.

19. There are two slim files of correspondence with Seymour de Ricci among the Dealers' Files in the Morgan's archives. One covers 1907-20, the other 1929-38; 
aware of Lee's early acknowledgment in The Library that he (and by implication Morgan) had been, if not deliberately deceived, certainly mistaken about the binding and provenance of the Folio. In his 1906 update of the Census Lee had written dejectedly, "Much detailed evidence has recently come into my hands to show that I had over-estimated its historic interest." ${ }^{20}$ Lee's evidence came from a retired civil engineer named Henry Richard Davis, to whom we will later turn.

The 1901 catalogue commissioned by J. Pierpont Morgan describes the "Sidney" First Folio thus:

SHAKESPEARE (MR. WILLIAM). COMEDIES, HISTORIES AND TRAGEDIES. PUBLISHED ACCORDING TO THE TRUE ORIGINAL COPIES. London, printed by Isaac Iaggard and Ed. Blunt, 1623.

Folio; FI RST EDITION, portrait by Martin Droeshout on title, in the original old calfbinding, with the arms of Sir Robert Sydney, Earl of Leicester, in gold on the sides.

This exceedingly fine copy of the FIRST FOLIO EDITION OF SHAKESPEARE'S PLAYS, probably the largest in existence, measures $13^{3 / 8}$ in. by $83 / 4$ in., and is full of rough leaves. It also has a very curious cancelled leaf, the last page (77) of the "Tragedie of Romeo and Juliet," and on the reverse (78) the commencement of the "Tragedie of Troylus and Cressida." This is said to exist also in the Sheldon copy belonging to the Baroness Burdett-Coutts. The late Mr. J.O. Halliwell-Phillips offered a large sum for this leaf. The copy is quite complete, but the title and verses have been repaired. ${ }^{21}$

Today the Morgan Library's records scrupulously indicate to researchers the provenance and condition of this Folio, but no one has ventured further, to trace the binding and text-block to their origins, or reexamine Lee's account of the sophistication of the copy. The present authors come to the Morgan's "Sidney" First Folio from different angles; Germaine Warkentin from her study of the Sidney family library, ${ }^{22}$ and Peter Hoare from his work on the Brownlowe collection at Belton

both are obviously incomplete. They suggest that de Ricci and da Costa Greene were well acquainted, and de Ricci was clearly in New York in 1919, which might have been the occasion for his remarks on the First Folio.

20. Sidney Lee, "Notes and Additions to the Census of Copies of the Shakespeare First Folio," The Library, 2nd ser., 7 (1906): 117.

21. Morgan 1901, 171.

22. Germaine Warkentin, "The World and the Book at Penshurst: The Second Earl of Leicester (1595-1677) and His Library," The Library, 6th ser., 20, no. 4 (1998): 325-46. 
House. ${ }^{23}$ Together we have found out a good deal about the sophisticating of the Morgan "Sidney" First Folio, though nothing we have discovered tells us anything about the Sidney family, the Brownlowes, or indeed William Shakespeare. The story of our investigations does, however, say much about the complex history of one particular copy of the famed Folio, and what that history can tell us about physical bibliography, sound and unsound provenances, the idiosyncrasies of collectors, and the murky annals of the book trade. The confusions of Sidney Lee are part - but only part - of the story.

The Morgan "Sidney" First Folio is distinguished by its height, the front board measuring $13^{5 / 8} \times 85 / 8$ inches [34.7 $\times 22 \mathrm{~cm}$.], the back board $1333 / 32 \times$ $85 / 8[34.95 \mathrm{~cm} . \times 22 \mathrm{~cm}$. $]$. The text block is $13^{3 / 8}[34 \mathrm{~cm}$.] tall, with a page width that cannot be estimated accurately. According to Peter Blayney, the Folio is a third issue, with the portrait in the third state. The distinguishing feature of this copy is the presence of both the prologue leaf cancel for "gg3" and "gg3" (mis-described as ggg5 in the Hartley catalogue) itself. Leaves noted in the Hartley catalogue as needing repair have been mended. Peter Blayney collates this issue as follows: ${ }^{24}$

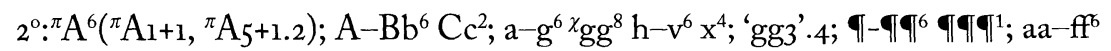
$\mathrm{gg}^{2} \mathrm{Gg}^{6} \mathrm{hh}^{6} \mathrm{kk}^{-\mathrm{bbb}^{6}}$

The inserted bifolium ${ }^{\pi} \mathrm{A}_{5}+1.2$ and preliminary leaf ${ }^{\pi} \mathrm{A} 6$ ("A Catalogue") are all short. In this copy $\mathrm{x}_{4}$ is followed by the cancellans gg 3 (containing the Troilus prologue) which has been supplied from another copy.

The arms on front and back boards are those of Sir Robert Sidney as they would have appeared before he was made Baron Sidney (1603), Viscount Lisle (1605); and earl of Leicester (1618). They bear the escutcheon of pretence of his wife, Barbara Gamage of Coity. The Folio currently exhibits two indications of previous ownership in addition to the binding. The first is the bookplate of Sir William Brownlowe, of Belton House, Lincolnshire; dated 1698 (Illus. 2). The second has a midnineteenth century gold design on ivory; it bears the words "Burnham Abbey Bucks" and an elaborate monogram intertwining the initials JT (Illus. 3); this is the personal bookplate of James Toovey. The Folio also

23. Peter Hoare, "The Perils of Provenance: Serial Ownership, Bookplates and Obfuscation at Belton House," Library History, 14, no. 3 (2001): 225-34.

24. Using Peter Blayney's revised version of his model collation (personal communication). 


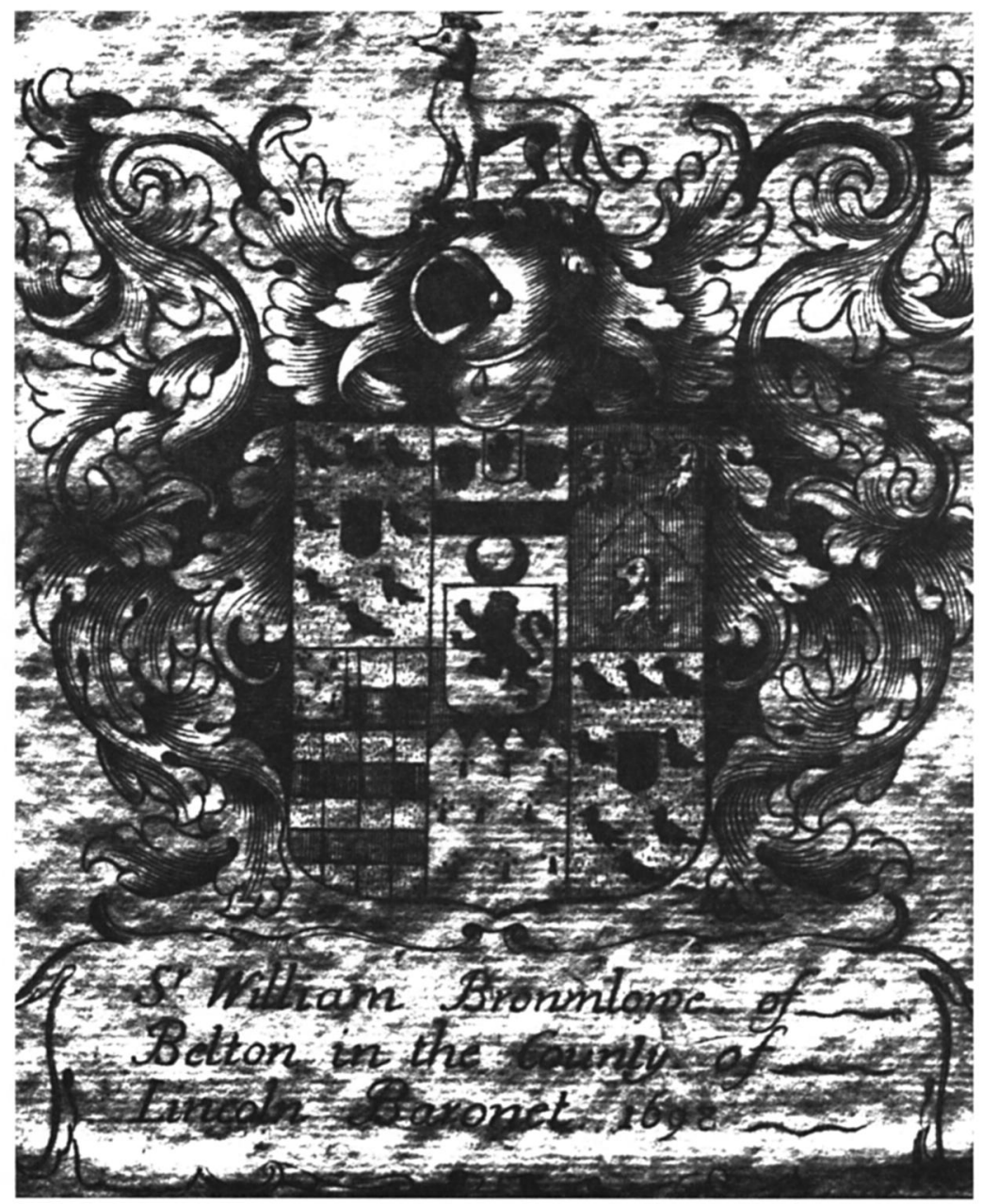

Illus. 2: Bookplate of Sir William Brownlowe of Belton, dated 1698 (The Pierpont Morgan Library, New York, PML 5122) 


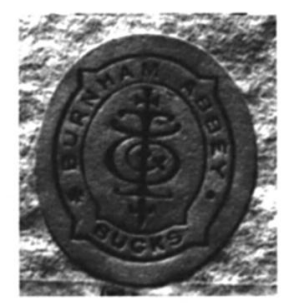

Illus. 3: Bookplate, "Burnham Abbey Bucks" (The Pierpont Morgan Library, New York, PML 5122)

bears a Pierpont Morgan Library bookplate, but reveals no other indications of ownership except the armorial stamp.

In December, 1990 Germaine Warkentin visited the Morgan Library to examine the Folio in connection with her search for volumes from the 1743 dispersal of the Sidney family library, and discovered from the library's records the nature of the book itself. Nicholas Pickwoad, the respected expert on binding structures, was conducting research in the library at the same time, and when invited to look at the Folio was generous in sharing his reading of the material evidence of its history. In Pickwoad's view the disassembling of the book was fairly expert. Nevertheless, he observed that the sewing supports which created the raised bands on the spine, and appeared to date from the first sewing of the text-block, did not line up with the sewing support slips laced into the boards; this was clear evidence that the boards had been re-used. The final endpaper is a replacement; the front endpaper may be earlier, but it has been repaired. There is a plain paper joint with no thread between flyleaf and pastedown, which is not a seventeenth century feature. The title label on the spine appears to be an early (that is, late seventeenth century) example of its kind (Illus. 4). Pickwoad pointed out that the visible evidence of the attachment of a chain shackle indicates that the book from which the boards with the Sidney arms were taken had been part of a chained library; yet private libraries in the seventeenth century were not normally chained, and the Penshurst and Belton collections were typical in this respect. Finally, Pickwoad remarked that the book, curiously, showed evidence that the catchplate had first been fixed to the cover and then apparently removed and fixed again nearby (see detail, Illus. 5). The "Sidney" First Folio was thus doubly unusual.

This example of the First Folio consequently poses a series of interesting questions: who commissioned the recasing of the Shakespeare text block in a binding with Sidney associations, and when was it done? 

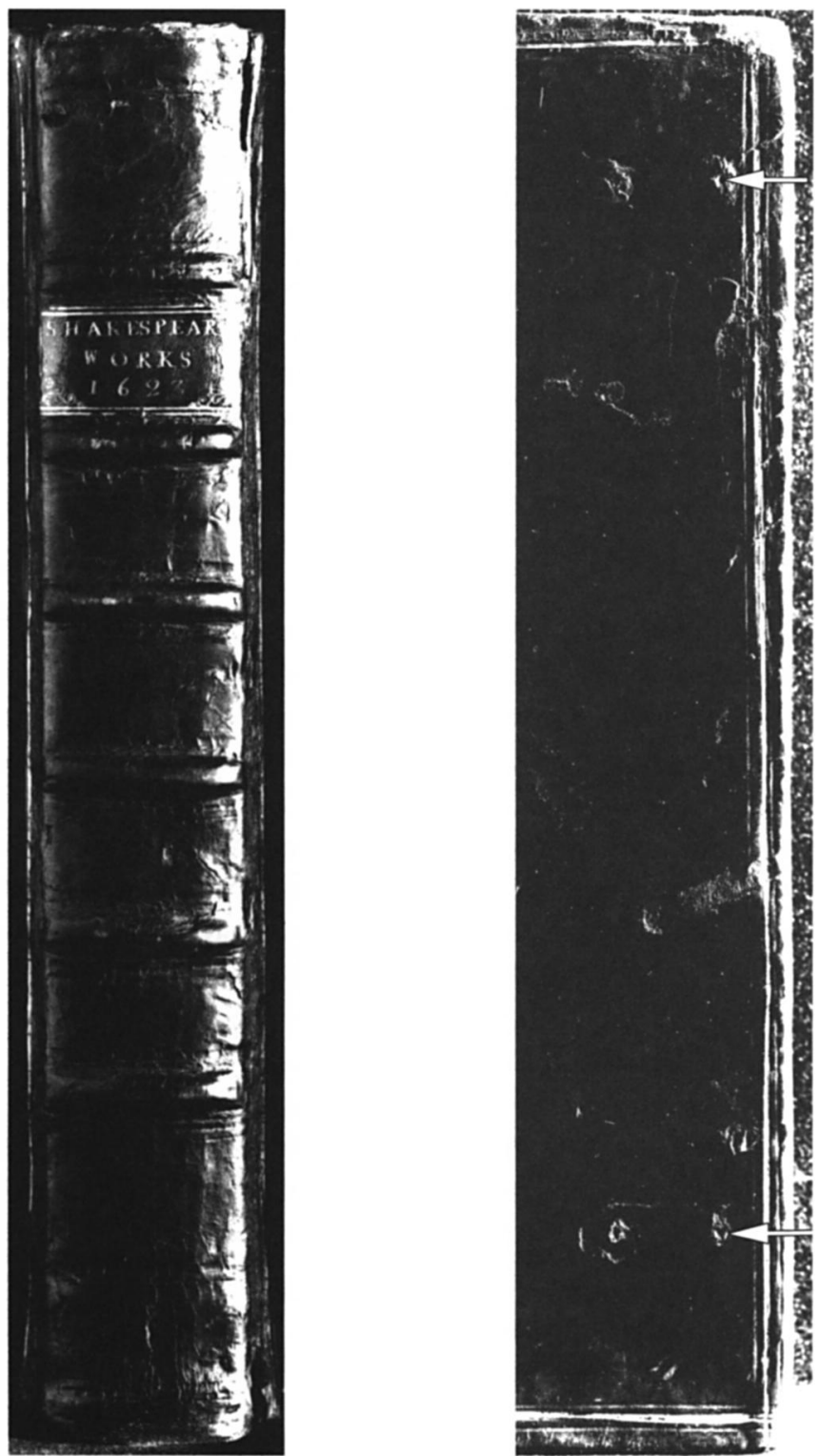

Illus. 4: Pasted-on spine label "SHAKESPEARE / WORKS / 1623" (The Pierpont Morgan Library, New York, PML 5122)

Illus. 5: Detail of fore-edge, with double clasp marks (The Pierpont Morgan Library, New York, PML 5122) 
Why does the binding display the evidence of catchplates affixed not once, but twice? Where did the text block - and presumably the spine label - come from? Did the Brownlowe bookplate come from the binding, from the text block, or perhaps from some other book or books? Who knew what about the provenance of the book, and how might the Folio have been described when it was offered to J. Pierpont Morgan? Some of these questions can probably never be answered, but with newly uncovered evidence some can. The results undermine Sidney Lee's account of the Folio's history, which for lack of rigorous examination has stood for over a century, ${ }^{25}$ and give us a much better, if still not entirely complete, picture of what happened as the components of the "Sidney" First Folio passed from owner to owner between the seventeenth century and 1899.

Between 1902 and 1924 Lee produced four accounts of the "Sidney" First Folio, revised one after another until it is almost impossible to untangle solid evidence from anxious self-defence. The first was in his 1902 Census, the second his 1906 "Notes and Additions to the Census of Copies of the Shakespeare First Folio," in The Library. The third, later in the same year, comprised that article separately reprinted and "revised to 24th May, 1906." His fourth and final word on the subject appeared in "A Survey of First Folios," in an essay included in the 1924 Studies in the First Folio published shortly before his death. ${ }^{26}$ These accounts are ragged and inconsistent; as a group they justify once again W.W. Greg's dismissal of Lee's scholarship on Shakespearean editorial problems in his 1903 article in The Library, where he pointed to Lee's "cheerful confidence of assertion" and his tendency to commit himself "unreservedly to statements which require qualification or explanation."

25. West is still heavily reliant on Lee's various accounts of the Folio in his description of the book (West 171) in West $S F_{2}, 226-7$. For reservations on West's limitations with respect to provenance, see Marc Vaulbert de Chantilly's review of West SFF , Book Collector 51, no. 2 (Summer, 2002): 299.

26. The 1902 Census (noted above); followed by Lee's "Notes and Additions to the Census of Copies of the Shakespeare First Folio," The Library, 2nd ser., 7 (April 1906). Independently reprinted, "revised to 24th May, 1906" (London: Oxford Univ. Press, 1906). Finally, see Lee, "A Survey of First Folios," in Studies in the First Folio (London: Oxford Univ. Press, 1924), 78-105.

27. Greg, "The Bibliographical History of the First Folio," 26o. For the comments in Greg's private notes, see West $S F F_{1}, 4^{-1}$ and n. 160. For later reserva- 
In the 1902 Census, where the Folio appears as number XXXVII, Lee was forced to base his description on the 1901 Morgan catalogue. To his credit, he had attempted to see the volume itself, in 1901-2 making several efforts to examine or at least obtain reports on Morgan's copies of the First Folio, but found that they were inaccessible. J. S. Morgan, Pierpont Morgan's nephew, wrote to him on 9 April 1902,

Mr. Morgan's two fine copies are packed up in boxes, along with a large number of other books in one of the Safe Deposit Vaults in New York. This fact makes it a most difficult matter to get at the books for the purposes for which you want them. The more important one of two was Mr. Tooveys and is pretty well described in the catalogue of his collection....Were Mr. Morgan's books on the shelves in his library it would be his pleasure to forward your interest in any way he could. ${ }^{28}$

The description Lee drafted was thus not based on a personal examination of the Folio (in fact he may never have seen it, then or later), and contains at least two errors. He relates that the book is

said to be originally c. 1623 in library of Robert Sidney, second Earl of Leicester (1595-1677). The arms of this nobleman are stamped on cover. Acquired c. 1860 by Leonard Laurie Hartley, and sold at sale of his library, May 3, 1886, to James Toovey, the London bookseller, who carefully restored it. It was purchased with James Toovey's private library by the present owner in 1899 . CONDITION: the original leather binding bears the Earl of Leicester's arms; it was labelled "Shakespeares Works, 1623," and had remains of old silk tape strings. Title page is from another original, and has been introduced into the volume since the Hartley sale (Cf. The Hartley Sale Catalogue, 1886). ${ }^{29}$

Robert Sidney was the first, not the second Sidney earl of Leicester, and the statement that Hartley acquired the book c. 1860 is quite wrong. There are no remains of old silk tape strings, though the holes where they were fixed are evident.

Lee had been cautious, however, as the words "said to be originally

tions about Lee's work, see the kindly but frank memoir by A. F. Pollard, "Sir Sidney Lee and the 'Dictionary of National Biography," Bulletin of the Institute of Historical Research 4 (1926-7): 1-13, and Gillian Fenwick, The Contributors' Index to The Dictionary of National Biography, 1885-1901 (Winchester: St. Paul's Bibliographies, 1989), xvi-xxi. The new entry on Lee in the Oxford Dictionary of National Biography (2004) makes no mention of such reservations.

28. J. S. Morgan to Sidney Lee, 9 April 1902. SBTRC ER 85/6/1 (in envelope 1).

29. Lee, Census, XXXVII. 
c. 1623 in the library of Robert Sidney" would suggest. ${ }^{30}$ Revising his account of the book in 1906 he wrote,

Already I had reason to believe that the book had been perfected from the somewhat damaged copy, lacking the portrait and title, which had belonged to the late Leonard Lawrie Hartley. But I did not know what I have been lately told on good authority that the old binding...is a recent substitute, derived from some other ancient tome, for a different old binding, stamped, it is said, with a bishop's armorial bearings, which covered the volume when Mr. Hartley was its owner. ${ }^{31}$

His good authority was Henry R. Davis, described by Lee as living at Clissold House, Clissold Park, a Victorian suburb of London. ${ }^{32}$ In a long footnote Lee related that Davis had "followed the history of $\mathrm{Mr}$. Morgan's copy very closely [and] owns the millboards of its original binding, which was, he tells me, stripped off after Mr. James Toovey bought it for £250 at the Hartley sale on 19th April, 1887." ${ }^{33}$ Davis must have written to Lee or spoken directly with him between the publication of the Census and the writing of the "Notes and Additions," but no evidence of that exchange remains. A retired civil engineer and book collector, Davis owned a First Folio himself, though as he wrote to Lee in August, 1906 it lacked fourteen leaves and had 67 defective ones. ${ }^{34}$

In the same footnote Lee reported that he had traced some of the earlier owners of the Folio text block. The earliest known was Sir John

30. Throughout his discussions of the Folio, Lee persists in the error that the arms on the binding were those of Robert, second earl of Leicester (1595-1677) and not those of Robert, the first earl of Leicester $(1563-1626)$, a fact known to James Toovey before his death in 1893 , as we shall see. Furthermore, the dating of Toovey's purchase was incorrect, a detail Lee later did amend.

31. Lee, "Notes and Additions," 117, and see note 1.

32. Lee corrected the erroneous address in the revised reprint of his article. Clissold House, built for the banker Jonathan Hoare about 1800 , had been in the hands of the borough of Stoke Newington since 1889, as the center of a public park (which it remains). Davis lived nearby at Thistleton House (otherwise no. 1 Clissold Road); the building still stands but no longer bears that name.

33. Lee, "Notes and Additions," 117 n. 1. Note that Lee now corrected his original statement about the date of the sale to Toovey.

34. Davis to Lee, ${ }_{15}$ August 1906. SBTRC ER 85/6/1 (in envelope 4). Davis's copy, which was unbound, is XIV in Lee's supplementary series ("Notes and Additions," $27-8$ ) and thus is termed Lee +14 by West. Today it is located at the Library of Congress (PR 2757 .A1 1623; Batchelder Coll.). It appears as West 157 in West $S F F_{2}$, where its murky provenance is sketched; see 200-2. 
Sebright of Beechwood, Hertfordshire (a sale in 1807), and the book had also been owned by Professor Robert Willis, FRS of Cambridge. But Lee was not entirely certain about the later career of the Folio; Willis's copy, he said, "seems to have been sold" at Hodgson's Rooms in 1872 for only $£_{22}$. 10 s "because of some unjustifiable misconception about a leaf in the middle of the volume," and Hartley "appears to have been the purchaser on that occasion." ${ }^{35}$ (Our italics in both cases.) It is evident that he had little or no documentary evidence either about Willis's purchase of the book, or its sale; he may simply have been making inquiries of friends in the trade. No evidence of Sebright's or Willis's ownership remains on the volume, but we assume that the distinctive height of the book served as Lee's clue, as it has had to serve us in following subsequent events.

The separately published version of "Notes and Additions" issued later in 1906 and "revised to 24th May, 1906" is unchanged except for the correction of Davis's address. But on 15 August Lee received a letter from Davis that must have given him pause:

Dear Sir.

I have read your article in the Library, "additions to the Shakespeare Census," and would wish to make a few corrections - Leonard Hartleys copy of the ist folio was in plain sprinkled calf when I saw it at Messrs. Puttick \& Simpsons with no armorial bearings on the covers - Mr Toovey, I understand, gave directions to rebind the book in the calf covers with the bishops armorial bearings which I saw in his shop after it had been restored in Paris - With reference to my own defective copy there are only 14 leaves actually missing but 67 are defective, wanting portions of the text.

\& I remain Sir

Yours truly

Henry R. Davis ${ }^{36}$

The letter was presumably sent to clarify information Davis had written or related to Lee earlier; it is concise and factual, as befits a civil engineer whose profession required him to be precise about details. Davis makes no mention of Lee's statement that he had "followed the history of Mr. Morgan's copy very closely," and does not correct the information that he possessed the discarded covers, merely stating that he had seen the

35. Lee, "Notes and Additions," 117, n. 1.

36. SBTRC, ER $85 / 6 / 8(\mathrm{I})$, first of two files of "Correspondence on additions to the Census." 
book twice, once before the Hartley sale and once in Toovey's shop after it had returned from Paris. There appears to be no doubt, however, that he was talking about the Hartley copy, that it had first been bound in sprinkled calf, and that the calf binding had been replaced with covers bearing a bishop's armorial stamp.

Reminiscing two decades after the events in question about the uncertain business of chasing First Folio pedigrees Lee gave a more elaborate version of his earlier account. "After the publication of the 'Census,' I learned, from one who watched the process, the precise kind of restoration which Mr. Pierpont Morgan's First Folio underwent in London shortly before he acquired it in $1899 .{ }^{37}$ In 1906 he had said his new information came from Davis, though the engineer's subsequent letter makes no reference to his having "watched the process," whether after the Hartley sale in 1887 or "shortly before he [Morgan] acquired it in 1899." In 1924 Lee stated, despite the precise details in Davis's 1906 letter, that "the Hartley copy had an old, rather decrepit cover stamped with the armorial bearings of an eighteenth-century bishop," which was replaced by the Leicester binding, and that the old episcopal binding is "still in existence." ${ }^{38}$ But the episcopal binding would hardly have been old and decrepit if it had, as Davis averred, passed through the hands of a Parisian binder. Furthermore, it is unlikely that a man as precise as Davis could have mistaken the arms of a bishop, crowned with the obligatory mitre - particularly if the boards were still in his possession - for the Sidney arms; it should be kept in mind that the supralibros represents the arms of a mere knight, which Sidney was in 1600 . By 1924, however, Davis was dead and his books, as ordered by his will, had been sold. If it was indeed he who possessed the old binding, it has disappeared. ${ }^{39}$

The most charitable explanation for this confused account is that Lee simply no longer remembered the precise details of a story nearly twenty years in the past. In attempting to assemble his recollections he conflated information from various sources and assigned it vaguely to Davis. Indeed, it is possible that even in 1906 he may have been elaborating

37. Lee, "A Survey of First Folios," 95.

38. Lee, "A Survey of First Folios," 95-6.

39. London: Principal Probate Registry, will of Henry R. Davis (d. 3 December 1921); probate granted 26 January 1922. Davis's estate was valued at $\S_{17} 7,221.16 \mathrm{~s} .1 \mathrm{~d}$. Among other routine provisions for the liquidation of assets, he requests that his books and instruments be sold to help pay his funeral and testamentary expenses. The Davis Folio may already have been sold by 1919; see $W_{e s t} S F F_{2}, 201$. 
Davis's visit to Toovey's shop into the account of "one who watched the process" or casually attributing to Davis information that came from some other source. To do Lee credit, his 1902 Census marked an important transformation in studies of the history of First Folio copies, and in the two decades following he earnestly sought to correct his information if he could. However, today any account of an individual copy that is forced to rely on his descriptions should proceed with caution. To draft a fresh history of the "Sidney" First Folio we need to return to a critical reading of the available evidence, in which Lee's description will play a role, but a minor one.

The "Sidney" First Folio is exceptionally tall: $13^{5 / 8}$ inches $(34.7 \mathrm{~cm}$.). Thus the search for its component elements involves locating first, a documented First Folio text block of approximately $13^{3 / 8}$ inches $(34 \mathrm{~cm}$.) tall - perhaps a shade more to allow for trimming when the re-binding was done - and second, covers with the Sidney armorial stamp and of a size sufficient to contain it. Only about three dozen of the more than 4,000 titles listed in the Sidney family library catalogue, compiled c. 1654-65, have ever come to light. Robert Sidney's commonplace books show that his reading was wide and serious, ${ }^{40}$ but only fifteen extant volumes can be documented as having belonged to him, and only four of those bear his early armorial stamp: Asser, Elfredi regis res gestae (with other works) in the Morgan Library, a 1570 Polydore Vergil in the British Library, a Gerardus de Roo (1592) at Stanford, and one volume of Fougasses, Histoire generale de Venise (1608) that has remained at Penshurst Place ever since the dispersal of the old library there in 1743. A recent discovery is a single volume bearing his post-1618 Garter arms. ${ }^{41}$

40. On Robert Sidney's reading, see Robert Shephard, "The Political Commonplace Books of Sir Robert Sidney," Sidney Journal 21, no. 1 (2003): 1-30.

41. Sidney's armorial book stamp on the British Library's Polydore Vergil, $A n-$ glicae bistoriae libri vigintiseptem (Basle: T. Guarinus, 1570; BL c.64.i.6) is discussed (with errors in the heraldry) by Cyril Davenport, English Heraldic BookStamps (London: A. Constable, 1909), 321-3. The Morgan copy of Asser is Elfredi regis res gestae ([London]: John Day, 1574, PML W 13 B). The Stanford copy of Gerardus de Roo, Annales rerum bello domique ab austriacis hapsburgicae gentis (Innsbruck: J. Agricola, 1592, Special Collections, KB 1592 .R6f) has sparse annotations in Robert Sidney's hand and is cited in his commonplace books. Still at Penshurst is Th. de Fougasses, Histoire generale de Venise, vol. 2 (Paris: Adrien 
His son the second earl (also a Robert) was an assiduous purchaser of books - in fact it was he who was the real builder of the library - but the second earl was a book user, rather than a connoisseur, and rarely bothered to put his name in the volumes in his possession, let alone mark them with his arms.

There is, however, one occasion on which a number of books were bound with the Sidney armorial stamp on them. In 1600 Sir Robert Sidney - not yet the earl of Leicester - donated $£ 100$ to assist his good friend Sir Thomas Bodley in stocking the reestablished University Library at Oxford. Fifty-five titles were bought with Sidney's gift, were duly listed in the Library's Benefactors' Register (Illus. 6) ${ }^{42}$ and soon after appeared in the printed catalogue of $1605 .{ }^{43}$ All were learned works, all were published before 1600 , and the bindings of the substantial number still remaining in Bodley bear the arms of Robert Sidney as they were before he became Viscount Lisle and eventually earl of Leicester. So do several volumes from the donation that sooner or later escaped the Bodleian. ${ }^{44}$ These books, unlike the extant bindings known to have once been in the Penshurst library, bear the marks of the catchplates by which the chains then used in the Bodleian were attached to the front covers of the books. But there is more: a volume at St. Catha-

Perier, 1608), with a 1616 signature of Robert Sidney using his then title of Lord Lisle. Philip Oldfield has recently identified Sidney's post-1618 Garter arms on the binding of a copy of François Garasse, Les recherches des recherches $\Xi$ autres oeuvres de Me E. Pasquier (Paris, 1622) in Bishop Hurd's Library, Hartlebury Castle (A.g.32).

42. Bodleian Library Benefactors' Register, vols. 1-2 [Microfilm WH/558]. Anno MDC., 12 (Library Records b.903-4).

43. Thomas James, Catalogus librorum bibliothece publice quam vir ornatissimus Thomas Bodleius eques auratus in Academia Oxoniensi nuper instruit (Oxford: Joseph Barnes, 1605).

44. Pietro Bizzari, Senatus populique Genevensis rerum domi forisque gestarum historiae et annales (Antwerp, 1529), Cambridge: St. Catharine's College, B.2.9; Avicenna arabice (Rome, 1593), Oxford: Christ Church, MB.2.4; Johannes Pistorius (Nidanus), Polonicae bistoriae corpus (Basle, 1582), London: St. Paul's Cathedral 16.B.4; Fulvius Ursinus, Familice Romanae quae reperiuntut in antiquis numismatibus (Rome, 1577), Oxford: Trinity College R.12.3. In addition there is a copy of Johannes Pistorius, Illustrium veterum scriptorium, qui rerum a Germanis...reliquierunt (Frankfurt, 1585), at London: National Art Library, Clements Collection, $\mathrm{CLE}_{3-4}$; it does not appear in the Benefactors' List but has both the Sidney arms and the Bodleian catchplate marks. 


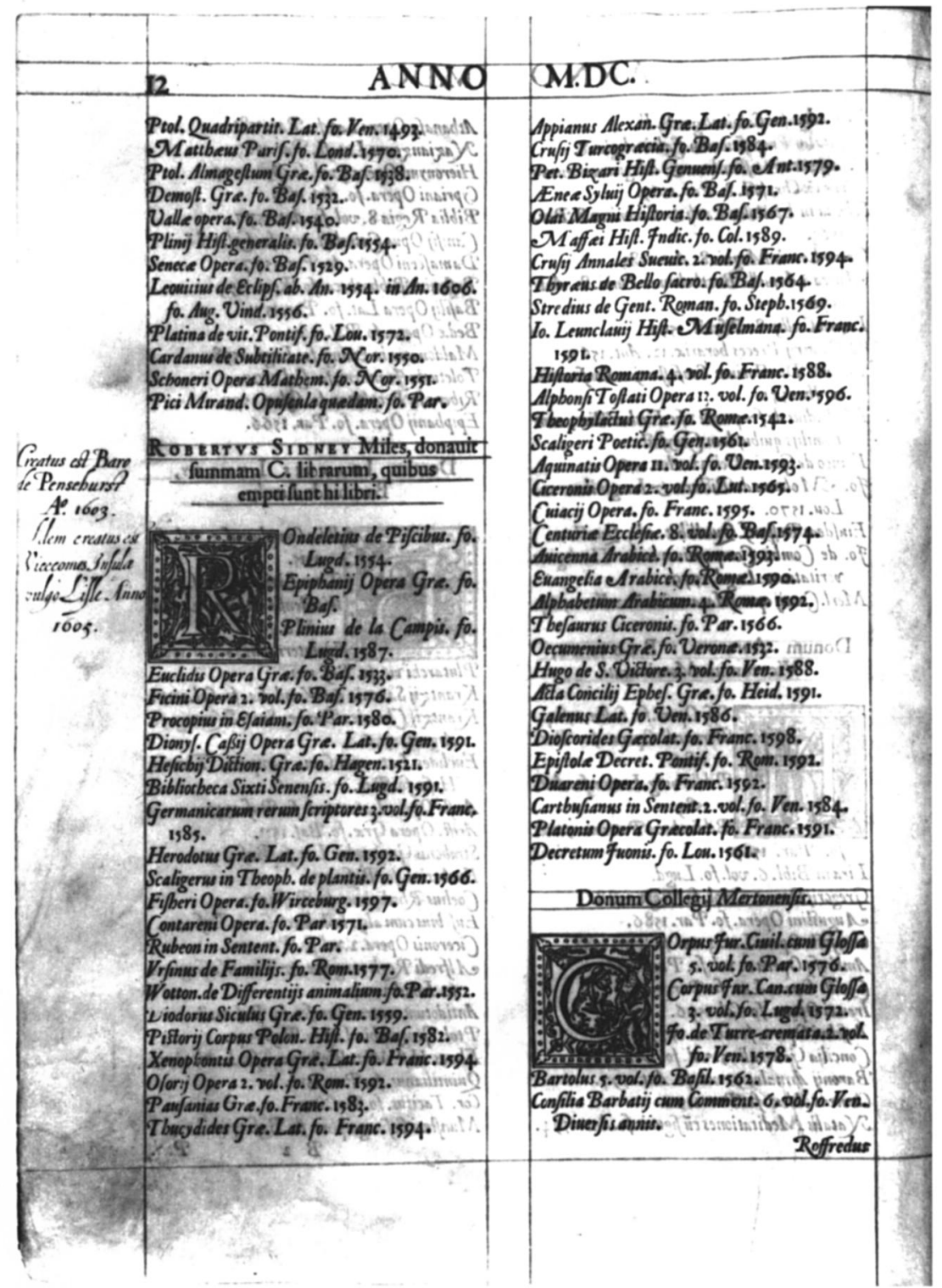

Illus. 6: Bodleian Library, Benefactor's Register: record of Robert Sidney's donation (Library Records b. 903, p. 12. The Bodleian Library, University of Oxford). 
rine's Cambridge and the cover of the Morgan remboitage bear two such marks, an indication that the original catchplates had been inadequately attached and had to be re-positioned. This is also the case with some volumes from the Sidney gift still in the Bodleian, and with a number of other Bodleian volumes bought in this period, according to Michael Turner, who described the phenomenon to Germaine Warkentin. ${ }^{45}$

From the presence of the catchplate marks it is evident, therefore, that the "Sidney" binding on the Morgan remboitage could not have covered a volume from the library at Penshurst, but came from one of those purchased with Sidney's donation to the Bodleian. Indeed, Robert Sidney never held the book in his hands; from 1589 he spent most of his time in the Netherlands acting as the English governor of Flushing. In November, 1599, he was pleading in vain for leave to return, which did not come until 30 October 1600 . As we learn from letters between Sidney and Rowland Whyte, his London agent, it was precisely then that the books donated to the Bodleian were purchased, bound, and dispatched to Oxford. "Mr. Bodeley hath the bookes away," wrote Whyte, 16 May 1600 , "and in my opinion they are of all others the fayrest gifte, and soe intended to be put in the best place of the Library." 46

In the mid-seventeenth century a number of early books were disposed of by the Bodleian as often newer, and it was then thought better, editions became available. ${ }^{47}$ It must have been at that time that a few of the fifty-five titles acquired with Sidney's $£$ ioo left the security of the library for which they had been purchased. ${ }^{48}$ Though we have not yet

45. Michael Turner, personal communication, 6 August 1991.

46. Rowland Whyte to Robert Sidney, 16 May 1600. Report on the Manuscripts of Lord De L'Isle \& Dudley Preserved at Penshurst Place, 6 vols. (London: His Majesty's Stationery Office, 1925-66), 2:462; see also 477, "Yf you had bene in England...."

47. Sir Thomas Bodley's draft of the Statutes prohibits any books from being carried away from the library, unless "if need so require, to be sold away for altogether, as being superfluous or unprofitable, or being changed for some other of a better Edition; or being over-worn to be new bound again..." Reliquiae Bodleianae (London: John Hartley, 1703), 28.

48. For example, the 1593 Avicenna arabice was bequeathed to Christ Church with the rest of his library by John Morris, Oxford's first Regius Professor of Divinity (for the use of his successors in office in perpetuity), as early as 1648 (Janet McMullin, personal communication, 9 December 2003); the book may never have been on the market. 
been able to identify which discarded folio supplied the covers of the Morgan remboitage, it has been possible to narrow down the possibilities (a task made the more adventurous by the discovery that the back cover is $0.25 \mathrm{~cm}$. taller than the front). Thus the Bodleian book that supplied the binding would need to have possessed covers at least $35 \mathrm{~cm}$. tall. If we eliminate from the list of the Sidney donation all those volumes that either still remain in the Bodleian or elsewhere, or are demonstrably (on the basis of comparison with known copies) too small or too large to have supplied the boards for a book of that height, we conclude that the covers of the Morgan Folio are most likely to have been taken from one of the nine titles listed in Appendix 1, the locations of which we have been unable to trace.

How and why were the covers removed from the unknown title? If the attrition rate of early books was high, their survival in more recent centuries was by no means secure. In 1952 the little-known collector Arthur Wrigley, recalling his first purchases around 1900, wrote with regret,

Five shillings was quite a lot to a youth whose books were bought with savings from lunches and fares.... Then one had to reckon with pulping for, coming back for some treasure seen yesterday, one would find the vendor filling sacks with his books after tearing off their leathern covers, reserving those bearing book-plates, which sold readily. ${ }^{49}$

Perhaps the Bodleian folio, now having wandered very far, was one of these.

As Wrigley's reminiscences suggest, it would be wrong to assume that the bookplates now on the Folio testify to the history of the text block; they may have traveled with whatever book was in the binding after it left the Bodleian. The 1698 bookplate is that of Sir William Brownlowe $\left(1665^{-1701)}\right.$. Unfortunately there is almost no evidence of Brownlowe's book ownership except the bookplate itself, which is, in fact, uncommon; no other books containing it have been found. Two copies are in the Franks Collection (Franks 4114 and *134) at the British Museum, and one is listed by J. H. Slater as having been sold for ten

49. Arthur Wrigley, "From a Correspondent," Times Literary Supplement, 27 June 1952; reprinted in The Book Collector 51, no. 4 (2002): 490-7; see also Nicolas Barker, "Arthur Edward Wrigley (1865-1952)," The Book Collector 52, no. 4 (2003): 529-36. For more on book pulping, see William Roberts, The Book-Hunter in London: Historical and Other Studies of Collectors and Collecting (Chicago: A. C. McClurg, 1895), xxiii. 
shillings in $1897 . .^{50}$ There are no examples in the extensive family library at Belton House, near Grantham in Lincolnshire (now in the ownership of the National Trust), ${ }^{51}$ though there are several copies of bookplates for Sir William's wife Dorothy and his widowed sister-in-law Dame Alice Brownlowe..$^{52}$ Despite his title Sir William spent little time at Belton, which was built by his brother "Young" Sir John; he had a London house in Arlington Street, St James's, which seems from the scant evidence to have been his main abode. Belton does contain many books belonging to seventeenth-century members of the family, but none of them shows any signs of having belonged to Sir William, and the absence of his ownership marks suggests that few, if any, of the very numerous books of his son, another Sir John Brownlowe (1690-1754; better known from 1718 as Viscount Tyrconnel) were inherited from his father: Sir William died intestate, with his affairs in considerable confusion, and his widow's will mentions no books. There is thus no indication of

50. J. H. Slater, Book Plates and Their Value (London: Henry Grant, 1898), 101. The Brownlowes are otherwise well represented in the Franks Collection, which includes, in addition to the plate in PML 5122, Sir William's smaller plate with two oval shields (Franks 4115 and ${ }^{*}{ }_{165}$ ) and copies of very similar large and small plates for his wife Dame Dorothy Brownlowe (Franks ${ }^{*}{ }_{13} 8$ and ${ }^{*}{ }_{132}$ ) as well as plates for his sister-in-law Dame Alice Brownlowe (Franks 4111 and 4112).

51. Peter Hoare, "The Perils of Provenance." The Belton library is still in the process of being catalogued for the National Trust's libraries database, but all the early books have been checked. Within the Franks Collection the so-called "Brighton" volume contains both the two bookplates with William's name and a pair of very similar ones for his wife Dame Dorothy Brownlowe (which may indeed have been the original designs, with William's being amended from them) as well as Dame Alice's.

52. It is likely that all these bookplates, like ones for their son Sir John Brownlowe and Dorothy's sister Mrs. Anne Mason (all dated 1698) were engraved in William Jackson's workshop. For the Brownlowes' bookplates, see Brian North Lee, "Gentlemen and Their Book-plates," in Property of a Gentleman: The Formation, Organization and Dispersal of the Private Library, 1620-1920, ed. Robin Myers and Michael Harris (Winchester: St Paul's Bibliographies, 1991), 42-76. In "Oxford Bookplates by William Jackson - New Light on the Brighton Collection" (The Bookplate Society Newsletter, no. 6 [June 1974]: 3-10), Anthony Pincott argues that the Brighton volume was in fact a pattern-book, using existing designs for clients to choose the style of their book-plates, and produces evidence to link it with the workshop of William Jackson. Interestingly, the 1704 bookplate of the earls of Leicester (which for reasons argued above does not appear in the Morgan Folio) came from the same workshop. 
what books he may have owned and certainly nothing to connect him positively with a First Folio. ${ }^{53}$

As for the eighteenth-century bishop whose arms Davis stated he saw on the Folio in James Toovey's shop, West reports only one episcopal owner, Thomas Percy of Dromore, among the known sales of the First Folio before 1799 (though his list includes two other clerics), and we have not been able to trace the bishop ourselves. To follow the history of the remboitage further, we must therefore turn to the problem posed by the text block.

If Sidney Lee found out about the rebinding of the Folio from Henry Davis, he may have learned something of its prior history from the record of its sale for $£_{20}$.10.0 at Hodgson's on 11 April 1872. The book had belonged to the Rev. Robert Willis, FRS (1800-75), holder of the Jacksonian chair of Natural Philosophy at Cambridge and a brilliant and innovative civil engineer in his day, best remembered for "Willis and Clark," the architectural history of Cambridge completed by his nephew J. W. Clark. At Hodgson's sale the catalogue description ran as follows:

1064 SHAKESPEARE'S (WILLIAM) COMEDIES, HISTORIES AND TRAGEDIES, published according to the true original copies, FIRST EDITION London, printed by W. Jaggard, E. Blount, Eंc. 1623

${ }^{*} *$ Note. - This copy wants title, portrait and Prologue to Troylus and Cressida, but has the rare Verses by Ben Jonson; none of the text is missing, though some few leaves are repaired at the fore edge, it is otherwise a clean and sound copy, size $13^{3 / 8}$ inches by $8^{1 / 2} 2$ inches.

AN UNUSUALLY TALL COPY, with Sir T. Seabright's book plate..$^{54}$

Evidently Hodgson's cataloguer was concerned about the completeness of the text; in the 1870 completeness, as then defined, was as important an issue as height. This copy, then, was unusually tall, and it had once

53. Lady Elizabeth Cust, Records of the Cust family, Series II: The Brownlows of Belton (London: Mitchell Hughes and Clarke, 1900), 171-84.

54. A Catalogue of the Valuable and Extensive Library of the Rev. Robert Willis, F.R.S. E'c....Rare Early Printed Books, Including the First Four Folio Impressions of Shakespeare;... which Will be Sold by Auction, by Messrs. Hodgson, at Their Auction Rooms, No. 115, Chancery Lane, W.C....on Monday, April 8th, 1872, and the Four Following Days. 4th day's sale, 61. Willis's other three Folios sold as follows: 2nd,

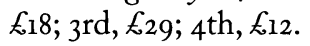


belonged to Sir Thomas Sebright. Sebright (1732-61) was the uncle of Sir John Sebright (1767-1846) of Beechwood, Hertfordshire. ${ }^{55}$ Sir Thomas, whose books his nephew inherited, had bought the library of seventeenth-century soldier and historian Sir Roger Twysden of Roydon Hall in Kent. ${ }^{56}$ Unhappily, the Folio text block does not appear to have been a Twysden copy, and we have not been able to trace its history before the Sebrights acquired it. ${ }^{57}$ Sir John sold many of his books at auction through Leigh and Sotheby on 6 April $18077^{58}$ the Folio bearing the bookplate of Sir John's father was item 747, and went to Payne and McK[inley?] for $£_{30} 0.10 .0 .^{59}$

The volume may have remained in booksellers' stock or passed through other hands for the next twenty or thirty years, but it was eventually acquired by Robert Willis at a date unknown. The next documented owner is Leonard Hartley, whom Lee believed had purchased the book at the Willis sale in 1872; Lee related that the low price came about because Hartley was suspicious of a leaf in the middle of the volume (Hodgson's description of it as "a clean and sound copy" seems to have been disingenuous). However, examining sale prices in 1898 when booktrade memories of such transactions were still fresh, Henry B. Wheatley tells another tale:

Hartley's copy was in poor condition, although very tall $\left(13^{3 / 8} \times 83 / 4\right)$, title with portrait wanting, page with verses mutilated, and some leaves mended. It sold

55. Most sources say that Sir Thomas was the father of Sir John, but he died unmarried, and Sir John was the son of his brother, who then inherited; see G. E. Cockayne, Complete Baronage (Exeter: William Pollard and Co., 1902), 2:4-5.

56. C. E. and Ruth C. Wright, eds., The Diary of Humphrey Wanley, 1715-1726 (London: The Bibliographical Society, 1966), 1:4 (entry for 4 March 1714/15).

57. See New York, Grolier Club, A Catalogue of the Books and Pamphlets Being Part of the Library of Sir Roger Twysden, Bart. of Royden Hall in the 17th Century: and Others since Collected. Nineteenth-century ms. copy of seventeenth-century catalogue.

58. A Catalogue of the Duplicates and a Considerable Portion of the Library of Sir John Sebright...also...Manuscripts...collected by Sir Roger Twysden and Mr. E. Lhwyd.... which Will Be Sold at Auction by Leigh and S. Sotheby...on Monday, April 6th, 1807 and Six Following Days [pages unnumbered]. Item 747 (fourth day's sale).

59. For Tom Payne and his various descendants and their partners over more than a century see Seymour de Ricci, English Collectors of Books and Manuscripts, 92-3. The reading "McKinley" in the annotated catalogue of the sale is uncertain, but for Payne and Mackinley see Roberts, The Book-Hunter in London, 241. (Thanks to James Raven for assistance with this identification.) 
in 1887 for $£_{255}$. Hartley gave $£_{5} 00$ for it to those who had bought it at a knock-out for $£_{75} .^{60}$

At a knock-out, a ring of bidders at an auction agree not to compete with each other for specific lots, and in a subsequent private meeting they "settle," that is, re-auction the books and share privately among themselves the savings made by not having bid them up. ${ }^{61}$ Unhappily, the auctioneer's catalogue of the Willis sale shows prices but not purchasers, and Lee's "seems to have been sold" and "appears to have been the purchaser" indicate that he had uncovered no detailed information about the sale. Wheatley was one of the founders of the Early English Text Society and a noted editor and theoretician of indexing. He reported accurately (as some have not) the price the Folio eventually brought at the Hartley sale in 1887 . If the story as he tells it is correct, an unknown member of the ring must have bought the Folio at Willis's sale for the recorded price of $£ 20.10 .0$, after the sale the copy was "settled" for $£_{75}$, and the bookseller who acquired it then sold it on to the credulous Hartley for what was a very high price for any Folio in the 1870 , let alone one not in the best condition. And with Leonard Hartley and his obsessive acquisition of books of every sort, we turn at last to events about which more can be learned.

Leonard Lawrie Hartley (1816-83) has been described as having a "maniacal enthusiasm for genealogical books [that] out did Sir Thomas Phillippss." ${ }^{2} \mathrm{~J}$. Corbet Anderson, in his preface to the printed catalogue of Hartley's collection (also used as the anonymous "Introductory" to the sale catalogue) depicts Hartley as "of a studious disposition, with great powers of application, and gifted with a retentive memory, having made himself master of a wide range of literature." ${ }^{63}$ William

6o. Henry B. Wheatley, Prices of Books (London: George Allen, 1898), 229.

61. See chapter 2, “The Ring,' Theory and Practice: A Digression," in Arthur Freeman and Janet Ing Freeman, Anatomy of an Auction: Rare Books at Ruxley Lodge, 1919 (London: The Book Collector, 1990), 29-57.

62. Nicolas Barker, Bibliotheca Lindesiana: The Lives and Collections of Alexander William, 25th Earl of Crawford and 8th Earl of Balcarres, and James Ludovic, 26th Earl of Crawford and gth Earl of Balcarres (London: B. Quaritch for the Roxburghe Club, 1978), 251.

63. Sale Catalogue (First Portion) of the Very Extensive EO Valuable Library of the Late Leonard Lawrie Hartley, esq.....sold....by Messrs Puttick E' Simpson on Monday, 
Roberts, of whom we will shortly hear more, relates that the obsessed bibliophile "would buy almost anything the dealers offered him, and at almost any price." ${ }^{64}$ Not surprisingly Hartley died a bankrupt, and his extensive collection was auctioned by order of the Court of Chancery at Puttick and Simpson's in three parts between June 1885 and April $1887 . .^{65}$ Part ii of the sale was scheduled for 3 May 1886, and the First Folio duly appeared as lot 250 . The catalogue description is of considerable interest, as being the first detailed account of the make-up of the text-block itself, and we give it here in full:

250. Shakspeare (W.). The first collected edition of Shakspeare's Comedies Histories and Tragedies. Published according to the True Original copies. Folio. London, 1623. The title, on which is Shakspeare's portrait, by Martin Droeshout, is wanting; and the leaf opposite, containing the ten lines of poetry by Ben Jonson is mutilated, although the verses themselves are intact. The volume commences $\mathrm{A}_{2}$ with the dedication to William, Earle of Pembroke, and Philip, Earle of Montgomery, signed by John Heminge and Henry Condell, the editors, and two of the three principal actors of Shakspeare's plays. The collation agrees with Lowndes, except in the following important points: B Henry VIII - ends p. 232; then a leaf is inserted from smaller copy, "The Prologue" and "The Tragedie of Troylus and Cressida," both unpaged; then follows p. 77, head line, "The Tragedie of Romeo and Juliet," signatures ggg5, crossed in black ink of ancient colour; signatures of Troilus and Cressida do not agree with Lowndes. The outer edge of p. 179 of the [sic] "The Tragedy of Richard the Third" has been mended; one corner of leaf containing pp. 229-30 is a little torn; and leaf comprising pp. $23^{-2}$ is both rent and stained. On p. 60 of "Romeo and Juliet" six lines are scored with ink; leaf 67 of the same tragedy has been mended; and further on, so also has p. 273. But generally the book is clean.

The present is a singularly large copy, its pages measuring $133 / 8 \times 83 / 4$ in., that is, $1 / 4$ in. larger than the Syston Park copy, described in the Catalogue of Sir J.H. Thorold's Library as "The largest and finest copy known."

June 1st, 1885, and Nine Following Week-days (1885), and subsequent portions; hereafter, Hartley Sale Catalogue). Anderson's catalogue is A Catalogue of the Library of the Late Leonard Lawrie Hartley, Esq. (London: Blades, East and Blades, 1885-7).

64. Roberts, The Book-Hunter in London, 87.

65. The annotated Hartley sale catalogue is British Library: S. C. Puttick and Simpson, Part i, 1 June 1885, S-C P. 224(7); Part ii, 3 May 1886, S-C P. 233 (1); Part iii, 18 April 1887, S-C P. 233 (2). We are grateful to John Goldfinch for assistance in locating all the parts and helping to interpret the annotation. 
The volume remains in the original leather (broken) binding, with backbands; attached are remains of silk tape strings; it is labeled on back "Shakspeare's Works, 1623." 66

This description provides three points useful to our discussion. First, the copy is described as unusually tall; second, the binding is said to be original (though broken), with a spine label such as that currently on the book, and the remains of old silk tape strings. Third, nothing is said of any arms on the binding, or of the Sebright or Brownlowe book-plates. The Hartley First Folio appeared, thus described, as lot 250 in part ii of the sale, in May 1886. The annotated auction catalogue indicates that at this first appearance a reserve price of $£ 250$ was set, but the book was bought in at $£ 220$. In part iii of the sale (April, 1887) where it appeared as lot 478 , with precisely the same description, a commission bid was left by Cole for $£_{1} 60$, but the book sold to the distinguished Piccadilly bookman James Toovey for $£ 255$.

James Toovey (1814-93, see Illus. 7) had been apprenticed to a bookseller at the age of fourteen. He at first set up business on his own at 36 St. James's Street, but in 1854 on the death of William Pickering he took over the business at 177 Piccadilly, which came to be known as Toovey's "Temple of Leather and Literature" (Illus. 8). He forged an early association with the Earl of Gosford, whose Aldines he would eventually purchase; in 1856 they caught a book thief together. ${ }^{67}$ During its existence the shop, wrote William Roberts, was visited by "all the prominent book-hunters and a legion of eminent people who have been more than book-collectors. In those leisured times Toovey's, like Hatchard's further along the street, was something of a resort for literary folk generally...."68 Toovey was known as "the Roman Catholic bookseller," ${ }^{69}$ he also published some Tractarian works. Sidney Lee remarks that Toovey, along with Bernard Quaritch and Frederick Ellis, was a competitive

66. Hartley Sale Catalogue, ii, 52-3. The Syston Park copy belonged to Sir John Thorold of Syston Park (by coincidence very close to the Brownlowe seat at Belton); it was later owned by Robert Hoe and is now Folger 7 (Lee 35, West 65).

67. Illustrated London Nerws (29 November 1856), clipping laid into Toovey's annotated copy of $A$ Catalogue of an Extensive and Extraordinary Assemblage of the Productions of the Aldine Press (London: James Toovey, 1880). PML 40626, once owned by Curt Buhler.

68. Roberts, The Book-Hunter in London, 254.

69. Barker, Bibliotheca Lindesiana, 253, quoting Lord Crawford. 


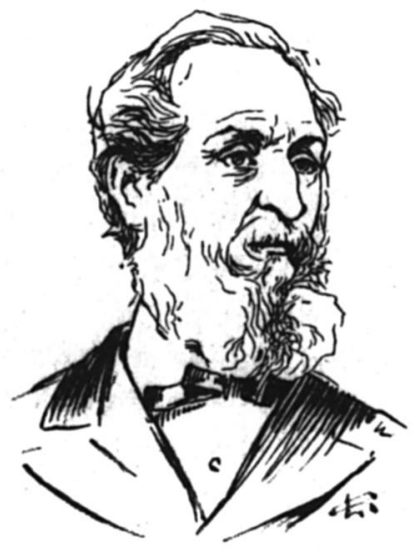

James Toovey, Bookseller.

Illus. 7: James Toovey, from a sketch in Roberts, The Book-Hunter in London (1895), 253 .

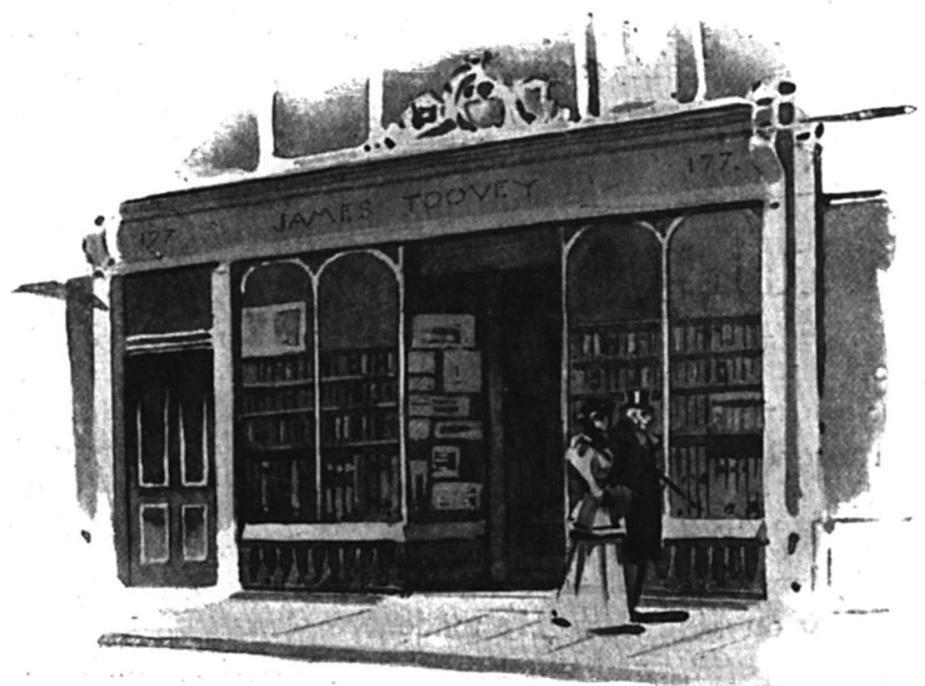

James Toovey's Shop, Piccadilly.

Illus. 8: Toovey's Piccadilly shop, from a sketch in Roberts, The Book-Hunter in London (1895), 254. 
participant in the busy trade in First Folios during the nineteenth century. ${ }^{70}$ Toovey had handled a number of First Folios in his time, indeed there was a Folio in his sale in 1894 (lot 2853). ${ }^{71}$ As a Philadelphia correspondent wrote to Lee, "When in London, in the summer of 1877 , I much enjoyed visiting the old book-shops. At James Toovey's on Piccadilly, I found copies of the first four folios, and finally bought them, during that summer, as a present to my father, the late George L. Harrison, who had collected a noteworthy private library."72

Toovey was especially knowledgeable about bindings. As a bookseller he would in the normal course of events have commissioned bindings, indeed his binding ticket can still be found. ${ }^{73}$ William Roberts's appreciative description of the bookseller, whom he pairs in repute with Bernard Quaritch, notes that Toovey was

very particularly the great authority on bindings. He made a strong speciality in old French morocco bindings, and during his frequent visits to France brought back large buyings of them. Toovey bought notable books, but unless they had the second qualification of being in a good state, and the bindings valuable, he was less anxious about them. Given a notable book in a notable binding, he would buy it at almost any cost. ${ }^{74}$

The Hartley First Folio, if we are to believe the description in the Puttick and Simpson catalogue, may have been a notable book but it was certainly not in a notable binding.

Lot 250 of the Hartley sale came up on Monday, 3 May, and as related above the book was bought in for lack of a purchaser, or at least an

70. Lee, Census, 12.

71. Catalogue of the Valuable and Extensive Stock of Books of Mr.J. Toovey Which Will Be Sold by Auction by Messrs. Sotheby, Wilkinson $\&$ Hodge... On Monday, the 26th of February, 1894, and Eight Following Days (henceforth Toovey Sale Catalogue), 155 .

72. Charles C. Harrison to Lee, 31 July 1901, SBTRC, ER 85/6/1 (in envelope 9). His copy, now at Chapin Library, Williams College, Williamstown, MA, is West 154. Among other First Folios that passed through James Toovey's hands is Folger 13 (West 71), the Gosford copy, which he sold on two occasions (West $\left.S F F_{2}, 159\right)$; West also notes the copy, referred to below, that was last mentioned in the sale of Toovey's books in 1894 (West $\left.S F_{2}, 305\right)$ and has not been further traced.

73. Charles Ramsden, London Bookbinders, 1780-1840 (London: B. T. Batsford, 1956), 141. For his binding ticket see Folger Shakespeare Library M2142, John Milton, Paradise Lost: A Poem in Ten Books (London: S. Simmons for T. Helder, 1669).

74. Roberts, The Book-Hunter in London, 253. 
adequate bid. ${ }^{75}$ James Toovey or his agent attended the sale of 3 May, for the firm purchased items $78,169,170$, and 254 . Given his purchase of the latter, he may have been in the sale room at the time the Folio (item 250) was put up, but it evidently did not attract him - or his agent there at the time. However when, on 19th April 1887, the Folio reappeared in the sale room as lot 478 in part iii of the Hartley sale, Toovey was the successful bidder, paying $£_{2} 255$ according to the annotated catalogue. ${ }^{76}$ Given the easy-going attitude of the trade to the sophistication of books, ${ }^{77}$ a First Folio with a dull and broken binding would have held some promise for a bookman with Toovey's interest in, and experience with, bindings. If adequate covers could be found, this tall - and consequently to be prized - volume could be improved. Possibly his interest in Hartley's worn volume the second time it appeared was prompted by the fact that in the meantime he had acquired an attractive set of covers not only of the necessary size, but with an armorial stamp of some sort. Within six months, as we shall see, he was writing to Lancaster Herald to inquire about an armorial stamp in his possession.

At any rate, having obtained the book for himself, Toovey - so experienced with bindings - could proceed to transform the well-worn object. However, in this case it may not have been with the aim of selling the result to a client, but of adding to his personal library. In the last two decades of his life Toovey had become a collector, purchasing among others the collection of Aldines from his old friend Gosford by private contract in 1878. According to his obituary in the Stationery Trades Journal for September, 1893, "By his death [Mr. Toovey] leaves a library at his Hendon residence, which for its value and antiquity can hardly find an equal. He was a bibliophile in its truest sense, judging from his marvelous collection of old and rare books. He was the fortunate possessor of a first edition of Shakespeare, for which he had declined an offer of more than $£ 1000 . "{ }^{\prime 78}$ Perhaps coincidentally, Lee later

75. Hartley Sale Catalogue, part ii, 52.

76. Hartley Sale Catalogue, part iii, 75 .

77. See especially Nicholas Poole-Wilson's remarks on the trade in bindings in M. M. Foot, Carmen Blacker, and Nicholas Poole-Wilson, "Collector, Dealer and Forger: A Fragment of Nineteenth-Century Binding History" in Eloquent Witnesses: Bookbindings and Their History, ed. Mirjam M. Foot (London: The Bibliographical Society, 2004), 277-9.

78. Stationery Trades Journal 14 , no. 163, 30 September 1893, 390. 
reported Morgan paid approximately $£_{1}, 000$ for the "Sidney" First Folio in $1899,{ }^{79}$ this at a time when copies of the First Folio were selling for an average of $£ 249 .^{80}$

In the decade before Morgan's purchase, information about Toovey's prized First Folio must have been circulating in the book trade. It was mentioned in his obituary, but curiously without any reference to the presence of the Sidney arms on the binding. These were first mentioned in print by William Roberts in a list of First Folio owners, ranked by the book's size, published in his The Book-Hunter in London (1895); as he observed, "Height makes a great difference in a book of this sort." Roberts's list and its source we will return.) In July, 1896, three years after Toovey's death, the volume was drawn to wider attention in a Times article on the Shakespeare First Folios: "The largest and most desirable example in existence is that owned by Mr. C.J.Toovey [Toovey's son and heir]. It measures $13^{3 / 8}$ by $83 / 4$ inches, and is not only in the original old calf and full of absolutely uncut leaves, but has the arms of Sir Robert Sydney, Earl of Leicester, on the sides." 82 (This is the first and last mention of any uncut leaves.) Two years later the Westminster Gazette observed, "The tallest copy belongs to Mr. C. J. Toovey, and bears the arms of the Earl of Leicester. If offered for sale it would probably bring $£ 800$ at present." ${ }^{13} \mathrm{~A}$ Sidney family binding would have enhanced the book in Victorian eyes infinitely more than that of an eighteenth-century bishop, and the high sum James Toovey reportedly refused for the Folio and which it subsequently obtained when sold - would suggest that he

79. Lee, Census, 10. No documentary evidence of the purchase remains in the records of the Morgan Library.

8o. Figures rounded off; based on the prices cited in West $S F F_{1}, 95-7$. The calculation includes all copies he reports sold from April 1890 up to Morgan's purchase in June, 1899 and is in fact somewhat inflated by three other copies that fetched high prices: in 1891 , West 157 for $£ 840$; in 1896 , $£_{900}$ for Folger 14 (West 72, with figures in American dollars); in 1899, West 179 for $£_{1,700}$. Of the 21 copies sold during this period, 5 sold for under $£_{100}$, 10 for $£_{100-500,} 4$ for $£_{500-1,000 \text {, and }}$ two over $£_{1}, 000$. Prices rose noticeably in the following decade.

81. Roberts, The Book-Hunter in London, 141.

82. The Times, 16 July 1896, 10.

83. Westminster Gazette, 9 March 1898, 10. 
was indeed responsible for the rebinding of the text block in the Sidney covers.

There are several pieces of evidence that confirm this interpretation, and make it possible to trace - or in one or two places at least surmise what subsequently occurred. First, part of the Morgan "Sidney" First Folio's documentation, included today in a file with the book, is a letter of 28 January 1888 from Edward Bellasis, Lancaster Herald, to James Toovey, responding to a query, in a letter no longer extant, about the armorial stamp. Bellasis told Toovey that the arms were those of Robert Sidney, whom he correctly identified as the first earl (though as we have mentioned, they are those of Sidney before he assumed any of his titles) ${ }^{84}$ This shows that in January 1888 James Toovey possessed either a book or covers with the Sidney arms, but does not tell us what he might have done with them. However, at a date unknown between 1888 and his death in 1893 Toovey himself wrote out on an empty leaf of Bellasis's letter a list of nineteen important First Folios, ranking them from smaller to larger according to their size - even to the square inch - on the basis of references in Lowndes's Bibliographer's Manual, and adding some information about past or present owners of specific copies. ${ }^{85}$ (For the list, referred to below as the "Bellasis list," see Appendix 2 and Illus. 9.) Two entries in particular suggest that the list is not quite what it seems.

Entry number 16 in the Bellasis list reads: "(L.L. Hartley) J.T. for R.S. Turner (this had reprint Title) $13^{1 / 8} \times 81 / 2=111^{1 / 2}$ [square inches] this now figures I believe in Q's [i.e. Quaritch's] catalogue for $1200 £$ without any intimation." This seems to say that a relatively small Hartley copy had been bought by J. T. (James Toovey) for the collector Robert S. Turner (d. 1888), ${ }^{86}$ but was now being sold at a high price by Quaritch despite what Toovey regarded as an imperfection. There was no First

84. Edward Bellasis to James Toovey, 28 January 1888. New York: The Morgan Library, original letter in file associated with the book itself. Bellasis's own papers, which would have contained Toovey's query, have not survived (personal communication, R. Yorke, Archivist, College of Arms, 13 November 2002).

85. It is not clear who produced the misattribution of the armorial stamp to the second Robert Sidney rather than the first, about whom Bellasis had given correct information to James Toovey, since the herald's letter confirming the arms on the stamp was included with the volume when it was sent to Morgan.

86. For Turner as a collector (he specialized in French and Italian, rather than English books) see Bernard Quaritch, ed., Contributions Towards a Dictionary of English Book-Collectors (London: Quaritch, 1892), Part 8. 


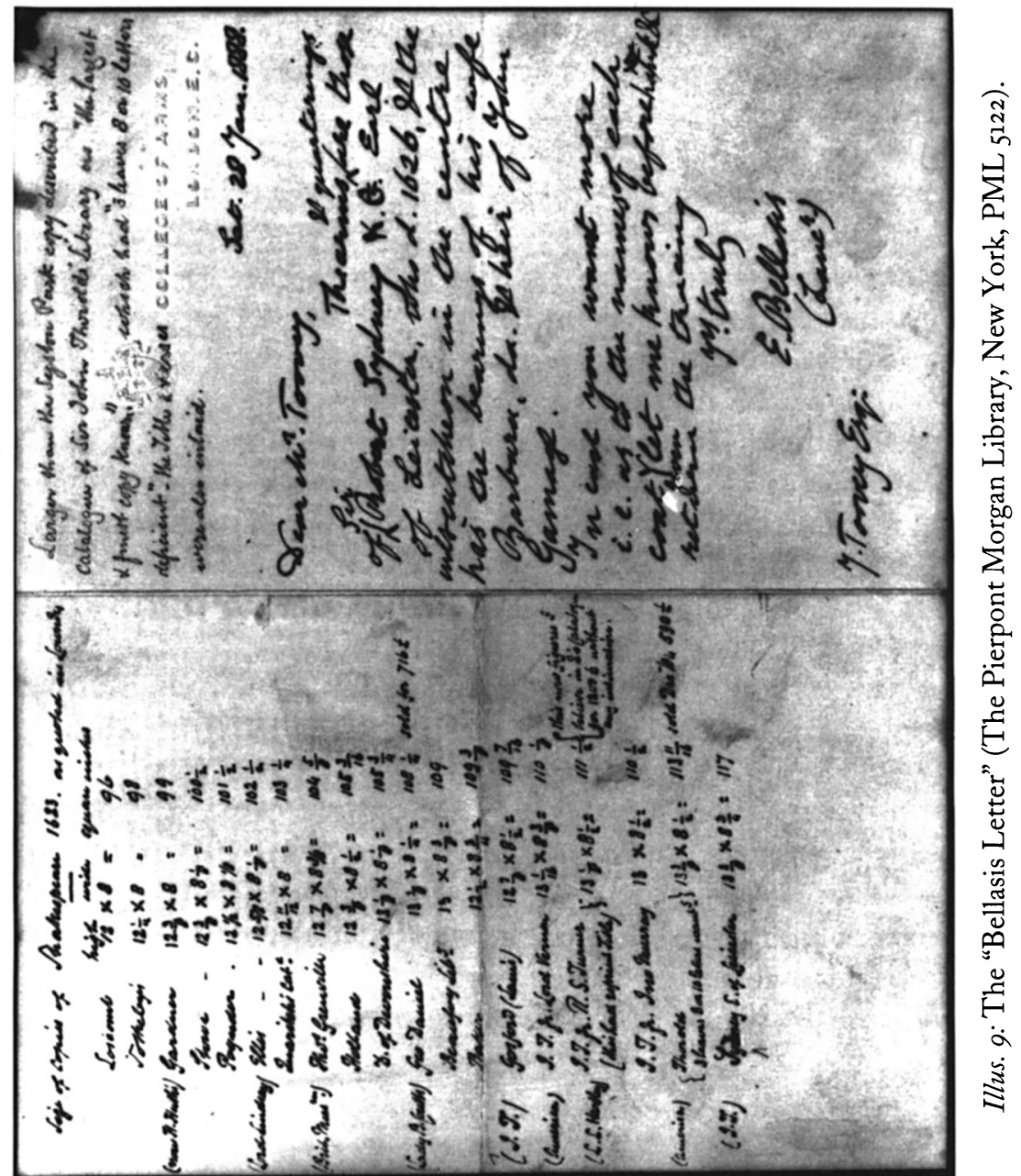


Folio in the sale of Turner's books in 1888, a fact Toovey will have been aware of, since he or his agent was present at Turner's sale when the place Shakespeare would have taken in the alphabetical sequence arrived, the firm having purchased a volume only seven lots later. ${ }^{87}$ The only First Folio listed by West as having belonged to R. S. Turner is $\mathrm{W}_{18} 3$ (West $\mathrm{SFF}_{2}, 238$ ) and its description and known provenance do not reflect the information above. West quotes Sidney Lee's statement that Turner bought his Folio c. 1850, then sold it privately in 1885 to the bookseller F. S. Ellis. The volume is now at the John Carter Brown Library at Brown University, Providence, RI, and West relates that their records show that Mrs. Brown bought it from Ellis and White in 1879 . Whichever version is correct, the book seems to have been in Ellis's hands before the Hartley sale in $1886-7$, probably without passing via Toovey. Furthermore, the price given in the Bellasis list seems high; Quaritch's catalogues for the period do not list any First Folio at such a price. ${ }^{88}$

The second problem entry is the last in the list, number 19. It reads: “(J. T.) Sydney E. of Leicester $13^{3 / 8} \times 83 / 8=117$ [117 square inches, corresponding within millimetres with the measurements of the Morgan Folio]." That is, James Toovey is the owner of a very large First Folio that had once belonged to Robert Sidney, earl of Leicester. Hartley's previous ownership of this copy goes unmentioned.

Toovey's list displays a certain conscious pride, rising as it does from negligibly small copies of the Folio to conclude in his own eminently large one. From it we can conclude first, that between January 1888, when he wrote to Bellasis, and his death in 1893 , James Toovey was unusually preoccupied with the size of certain First Folios. Second, Toovey seems not only to have owned a First Folio which he ranked as the largest and described as having a Sidney binding, but also describes another, which he had purchased from Hartley for R. S. Turner, and which despite its "reprint Title" had turned up in a Quaritch catalogue

87. Bibliotheca Turneriana. Catalogue of the First (Second) Portion of the Library of the Late Robert Samuel Turner... Which Will Be Sold by Auction, by Messrs. Sotheby, Wilkinson $E$ Hodge... on Monday, the 18th day of June, 1888 (Friday, the 23rd of November, 1888), etc. (London, 1888) second part, 236. Thirteenth day's sale, Friday, December 7, 1888, lot 4164 , Stephen, H. [i.e., Henricus Stephanus, that is Henri Estienne], A World of Wonders:... or a Preparative Treatise to the Apologie for Herodotus (1607) STC 10553.

88. Personal communication, Richard Linenthal, 4 June 2004. 
for what was then a very high price. However, Wheatley's anecdote about the knock-out after the Willis sale, and Leonard Lawrie Hartley's subsequent eagerness to buy the book at a high price, would suggest that Hartley did not possess another First Folio, at least in 1872. It is always possible that Toovey might have bought a very recently acquired First Folio from Hartley before that collector's death in 1883 , and sold it on quickly to R. S. Turner, who died in 1888 . The difficulty is that the existence of any such Folio cannot be documented by what is known either about Hartley or about R. S. Turner and his collecting. If Hartley did not own another First Folio - and none appears in his sale - and since no such connection with Turner can be documented, then this entry is likely fictitious. And since Hartley's name goes unmentioned in Toovey's entry on his own copy, we are justified in concluding that the old bookseller was either fantasizing a provenance for his "improved" Folio, or devising an outright deception. Either way, the Bellasis list had its consequences as we shall see.

The intensity of Toovey's interest in his very tall First Folio may well underlie a still puzzling feature of Henry Davis's letter to Sidney Lee of August, 1906. As we earlier saw, Davis wrote, "Leonard Hartleys copy of the ist folio was in plain sprinkled calf when I saw it at Messrs. Puttick \& Simpsons with no armorial bearings on the covers - Mr Toovey, I understand, gave directions to rebind the book in the calf covers with the bishops armorial bearings which I saw in his shop after it had been restored in Paris." We think nonetheless it is at least possible that given his pride in the book's size, so evident in the Bellasis list, and his apparent attempt to provide an invented provenance for it there, Toovey had the Folio rebound twice, and that Davis saw it in his shop between its first visit to the binder's and its second. In a bishop's armorial binding, displayed in Toovey's shop, the Folio would likely have been for sale. It is clear from the Bellasis list, however, that the "earl of Leicester" copy was intended to take pride of place in the library at Burnham Abbey, the bookplate of which it bears. ${ }^{89}$ Toovey's home was at Hendon in North London, but he is known to have rented, for several years in the $1880 \mathrm{os}$ and early 189os, a house built in the 1840s called Burnham Abbey, in the

89. The "Burnham Abbey" bookplate (not in Franks) appears in many of the books bought by J. P. Morgan from C. J. Toovey; our thanks to John Bidwell for this information. 
village of Burnham in Buckinghamshire, ${ }^{90}$ and a manuscript catalogue of his collection of which an early part is dated 1887 bears the title Burnham Abbey Library. The "Sidney" First Folio is listed there (part 3, page unnumbered) with its "rough leaves throughout, in the original calf binding...the Arms on the sides those of Robert Sidney, Earl of Leicester...." This entry must post-date the letter to Bellasis, since the arms are correctly attributed. The catalogue as a whole is devised to present an impressive picture of the library, and according to a note in the hand of Belle da Costa Greene on the flyleaf, it is inserted into "an eighteenth century French binding in the style of Derome de l'oiseau." So James Toovey's personal library catalogue proves to be a remboitage as well. ${ }^{91}$

When James Toovey retired in 1883 his business was carried on by his son, Charles James Toovey. The elder Toovey's will, signed on 30 October 1891 and proved on 20 October 1893, six weeks after his death, suggests that despite his apparent pride in his personal collection, he did not distinguish it, as an asset, from the fine library referred to in his obituary. At his death he was living not at Burnham Abbey but at "Manresa," Hendon, with his daughter Eliza, who was both an executor (along with Charles James, the eldest of his four sons) and the residuary legatee of his estate. He gives C.J. the option of purchasing within a year from his death "all books and manuscripts of which I may die possessed and my volume of autograph letters at the sum of Eight thousand pounds"; 92 otherwise the books are to be sold for the benefit of the estate. Until such sale, the books are to be left in the custody of Eliza

90. Burnham Abbey was an 184 os house built close to the ruined medieval religious house of that name. James Toovey's name appears in Kelly's Directories for Buckinghamshire as resident at Burnham Abbey in 1883, 1888, and 1891 (personal communication, Centre for Buckinghamshire Studies, 8 December 2004). In 1916 the medieval buildings were acquired for the Sisters of the Society of the Precious Blood, an Anglican order that still occupies the restored abbey.

91. James Toovey, Burnbam Abbey Library (3 parts in 2 volumes). Morgan Library MML 920.T67. The first part, containing the Aldines, is dated 1887; the Gosford and "Sidney" First Folios are in part 3. The catalogue has only recently become available after the Morgan's closure for renovations 2003-2006. We thank the Morgan's staff for supplying details of its appearance and contents.

92. London, Principal Probate Registry, will of James Toovey Esq., probate granted 20 October 1893 . 
Toovey. In fact, a sale of "the valuable and extensive stock of books of Mr.J.Toovey" promptly took place the following February. These books cannot have been comprised only of his commercial stock, since Charles James continued in the business after his father's death. Both the emphasis on bindings in the descriptions and the sum garnered during the nine days sale $\left(£_{7}, 090\right.$ 3s. $6 \mathrm{~d}$.) suggests that some of the lots must have been from among his personal books, the "Burnham Abbey Library" of his 1887 catalogue. The really valuable lots, however, were clearly held back by Charles James Toovey. ${ }^{93}$ Among the latter would have been the group of Aldines his father had bought from the earl of Gosford and retained so patiently through the 1880 s, along with a number of finely bound books, among them the "Sidney" First Folio.

It is no longer possible to trace the details of the 1899 transaction with Pierpont Morgan, since the library possesses no documents of this period referring to the book. However, it is likely that the description of the Folio in the 1901 Morgan catalogue came from details supplied by C. J. Toovey. This is made more probable by the wording of William Roberts's description of the Folio in the list he published in 1895 in The BookHunter in London. Roberts's list is an almost exact duplicate of the one inscribed on the Bellasis letter. One or two minor details about owners are altered, there are no calculations of square inches, and "Baker" (West 167) and its measurements are replaced by "Locker-Lampson $13 \times 83 / 8$ Rowfont [sic] Library" (West 151). ${ }^{94}$ Furthermore, R. S. Turner goes unmentioned; the copy attributed to him in Roberts's version of the list is described simply as "Hartley $13 \frac{1 / 8}{8} \times 8 \frac{1}{2}$," and the measurements repeat those attributed in the Bellasis list to the Turner copy. Roberts discusses Hartley's book-collecting in anecdotal detail elsewhere in The BookHunter in London $(87,114)$, but he does not mention his possession of this First Folio or any other. Finally, his version of the Bellasis list ends as follows: "Sir Robert Sydney, Earl of Leicester, with his arms on sides; original old calf, with lettering, full of rough leaves. $133 / 8 \times 83 / 4$. Mr. C.J. Toovey." How did Roberts obtain this information? As it happens, the words "full of rough leaves" are repeated exactly in a letter of C. J.

93. See Toovey Sale Catalogue, and Toovey's will, which gives detailed instructions for liquidating and redistributing the capital assets of the estate.

94. It is unclear why Baker was removed; its measurements are confirmed in the description of West 167. However, the addition of Locker-Lampson was probably as a result of the latter's unexpected death, which Roberts laments on 311-13. 
Toovey to Sidney Lee, written in 1902 (see below), as well as in Morgan's 1901 catalogue of the books he bought from the younger Toovey. Between 1893 when James Toovey died and 1895 when his book was published, Roberts must have been shown the Folio by C. J. Toovey. ${ }^{95}$ Given the similarities between the text of his list and the Bellasis list, he must also have been shown the herald's letter, and if the similarities in wording are considered, probably also a description - perhaps a draft attesting in authoritative words to the provenance of James Toovey's First Folio as stemming directly from the earl of Leicester.

C. J. Toovey's responsibility for confirming the state and provenance of the book is clear from his confident letter of 11 April 1902 to Sidney Lee, who if he had not actually been able to see the Morgan copy (still in the New York Safe Deposit Vaults) was attempting as we have seen to confirm its physical details:

The copy of the First Folio Shakespeare I sold to Mr. Pierpont Morgan belonged to my father's private collection. It is a very large one (measures $13^{7 / 8} \times$ $83 / 4$ in.) full of rough leaves, is in the original calf binding with old lettering piece and the Arms of Sir Robert Sydney Earl of Leicester, in gold on sides.... The copy is quite complete but the title and verses had been repaired. ${ }^{96}$

It is difficult to believe that C. J. Toovey - a bookseller and sometime bibliographer, his father's successor in business and his heir - did not know about the rebinding of the "Sidney" First Folio. Indeed, there remains a shadow over C. J.'s sale of at least one other of his father's books to Morgan. In Pierpont Morgan's 190 o “Toovey” catalogue, a copy of Les Cent Nouvelles Nouvelles, with some leaves supplied in facsimile or manuscript, is given the imprint: "Paris, Michel Le Noir, 1518."97 The erroneous description, like others in the 1901 catalogue, may have originated with the younger Toovey. In 1937 Belle da Costa Green wrote to Seymour de Ricci about this "rather tiresome book," having become aware that the preliminaries seemed to be eighteenth- or nineteenth-century German. ${ }^{98}$

95. In The Book-Hunter in London, Roberts twice refers elsewhere to the quality of Toovey's Folio, but without naming him: "the finest First Folio Shakespeare known" (255) and "the largest known First Folio edition of Shakespeare" (322).

96. C. J. Toovey to Lee, 11 April 1902, SBTRC, ER 85/6/1 (in envelope 11).

97. Catalogue of a Collection of Books Formed by James Toovey, 100. The entry notes that the book comes from the collections of Count Hoym and David Garrick (Hoym's armorial binding is illustrated).

98. Letter dated 14 June 1937 among Belle da Costa Greene's correspondence with Seymour de Ricci, 14 June 1937, Morgan Library (in "Dealers” files). 
The book, clearly not an early sixteenth-century French publication as claimed when C. J. Toovey sold it to Morgan, is now catalogued with the imprint "Cologne (Amsterdam), Pierre Guillard, 1701" (PML 22634).

C. J. Toovey, about whom we have found little more, seems to have remained in the book trade for a time. He compiled a catalogue of the library of the Scottish book-collector Sir Charles Tennant, published in 1896, and may have worked on other similar projects. ${ }^{99}$ His letter of 1902 to Sidney Lee was written from 177 Piccadilly, and he remained at that address until at least $1905 .{ }^{100} \mathrm{His}$ "valuable collection of autograph letters and documents" was sold at Sotheby's on ${ }_{25}$ April 1912, ${ }^{101}$ and he died in 1925 , aged 76 , leaving a gross estate of $£_{40}$,230.2s.1d. ${ }^{102} \mathrm{~J}$. P. Morgan died in 1913, and Belle da Costa Greene, one of the best book women in the business, took nearly twenty years to discover the truth about the book the younger Toovey had sold him. As for Sidney Lee, he was clearly embarrassed by the claims he first made for the remboitage and continued in a confused fashion to relate its story into the 1920 . In 1906 we catch what may be a shadowy hint of his consternation in a letter to him from Sir Edmund Gosse, dated 19 February:

My dear Lee:

Your information is extraordinary - and most interesting. There is no doubt that the darkest fraud is practised in these matters. But how is any protest to be made? I despair of awakening the public conscience.

Yours very sincerely,

Edmund Gosse. ${ }^{103}$

Gosse, as a respected man of letters and recently appointed (1904) the Librarian of the House of Lords, was well placed to comment on matters of fraud in the book world. We do not know what it was that Lee

99. Catalogue of the Library Collected by Sir Charles Tennant, Bart. Compiled by C. J. Toovey. Privately Printed at the Chiswick Press, 1896.

100. The Survey of London, vol. 29: The Parish of St. James Westminster, Part One: South of Piccadilly (London: Athlone Press, Univ. of London, for the London County Council, 1960), 253.

101. Catalogue of the Valuable Collection of Autograph Letters and Historical Documents, the Property of C.J. Toovey, Esq. which will be sold by Auction...on Thursday, the 25th of April 1912 (London: Sotheby, Wilkinson, and Hodge, 1912).

102. London: Principal Probate Registry, will of Charles James Toovey (d. 15 November, 1925); probate granted 9 February 1926.

103. SBTRO ER85/6/8/i (c). 
had written to Gosse (his letter has not been traced), but Gosse's letter to him, the date of which may point to the occasion of Henry R. Davis's first communication with Lee, is filed in the first of Lee's two personal folders of "Correspondence and Additions to the Census" and therefore almost certainly relates to Lee's investigation of First Folios.

Two final comments on the Folio as it exists today. First, as early as the Sebright sale (1807) it was described as wanting the title, and in Willis's sale catalogue this is expanded to note the missing portrait and Prologue to Troilus and Cressida. The description in the Hartley sale catalogue states that it still lacked the title-leaf, with its portrait, but had acquired the leaf, inserted from a smaller copy, containing the Prologue and beginning of Troilus and Cressida. The Morgan catalogue of 1901 states that the title and verses have been repaired. Lee's description of 1902 states that the title had been inserted from another copy since the Hartley sale; it must therefore have been inserted when the rebinding (whether once or twice) was carried out. In 1894 James Toovey's sale catalogue contained a parcel of such leaves and facsimiles from the First Folio and other editions (lot 2855). ${ }^{104}$

Second, though the mysterious binding with the bishop's arms is always a possibility, we think that the simplest explanation of the presence of the Brownlowe bookplate in the Folio is that it probably belonged to the "Sidney" binding. We are left to imagine which of the learned works paid for by Sir Robert Sidney and later disposed of by the Bodleian would have appealed to an unliterary aristocrat. The present authors' fancy (though we emphasize that it is only a fancy) rather leans towards Gulielmus Rondeletius's Libri de piscibus marinis in quibus vera piscium effigies expresse sunt (2 pt., Lyon, 1554, 1555), with its many small - and to a fisherman very delightful - illustrations. The Morgan Library owns a copy, and when we set the "Sidney" First Folio and their Rondeletius side by side, it seems to us at least a possibility.

In 1738 Sir Brownlow Sherard, whose aunt Dame Alice Brownlowe was the sister-in-law of Sir William Brownlowe (of the 1698 bookplate), married Robert Sidney's great-great-granddaughter Mary Sidney, and that is about the closest the families whose histories are involved in the Morgan's First Folio ever got to each other. In truth, the story of the 104. Toovey Sale Catalogue, 156. 
"Sidney" First Folio contributes little that is not already known to the history of the Sidney family, its friends and relations, or to the study of Shakespeare's text. However, if our investigation into the history of one copy of a famous book tells us nothing about the book-collecting of the Sidneys or the Brownlowes, it does show how little can, in the end, be taken on trust in matters bibliographical, even when respected collectors, dealers, and scholars are involved. More significantly, perhaps, it also shows how much each of the participants was a man of his times. If our argument holds true, within the space of two decades James Toovey, a respected bookseller of the old school and operating on principles accepted in the trade, devised the rebinding of a famous book in noteworthy covers - possibly even twice - though it seems he did so entirely to please himself. His son, operating on newer and more entrepreneurial principles, confirmed its improved provenance to an apparently credulous buyer. Sidney Lee, engaged in an ambitious bibliographical project, was shocked and embarrassed by the way contrivances routinely accepted in the book trade had transgressed his scholarly principles, and then cobbled together a narrative to explain what seemed to have happened. And despite the fame of First Folios in general, that narrative, with its many puzzling features, has not been re-examined until the present article.

Many such narratives might open up were we to look without illusion into the history not of the totemic object that the Shakespeare First Folio has become, but of the many specific copies of that not-very-rare book itself. Sidney Lee's 1902 Census did not provide the final word on the Morgan "Sidney" First Folio, nor did his anxious series of addenda, nor has the useful survey initiated by Anthony James West with the first two volumes of his The Shakespeare First Folio, nor, it is probably the case, has the present article. Yet even this partial and in some places still speculative account of the assembling of the Morgan remboitage suggests how much, despite the mystification that surrounds it, the Shakespeare First Folio remains a rich and continuing source of bibliographical knowledge in areas of book history quite outside those it occupies when garbed in its more dramatic costume as a bibliographical celebrity. ${ }^{105}$

105. Richard Landon relates that when he asked one of his contacts who had paid over six million dollars U.S. for the Abel Berland copy sold in 2001, he was told "think Hollywood" (Personal communication, 21 October 2005). 
Appendix 1

Possible Origins of the "Sidney" First Folio Binding

Below are listed those volumes in the list of Robert Sidney's donation of 1600 to the Bodleian Library that can no longer be located in the Bodleian or found elsewhere and which - based on comparison with other known copies - are of a size, close to $35 \mathrm{~cm}$., sufficient to cover the Morgan "Sidney" First Folio. For each item we give (a) the entry as it appears in the printed Benefactors List and (b) the entry in the 1605 Catalogue, with press-marks as given in that catalogue.

1. Centuriae Ecclesiae. 8 vol. Bas. 1574

Ecclesiast. Hist. Magdeburgens. Bas. 1569 [-1574] - Libri Theologici C.6.1[-8]

2. Dionys. Cassij Opera Grae. Lat. fo. Gen. 1591

Dionis Cassij lib. 25 Hist. Rom. Gr. Lat. 1591 - Libri Artium D.1.7

3. Epiphanij Opera Grae. fo. Bas. [n.d.]

Epiphanij opera Gr. Bas. 1544 - Libri Theologici E.2.9

4. Euangelia Arabice. fo. Romae. 1590 Evangelia 4. Arabicè. Roma. 1590 - Libri Theologici E.3.6

5. Galenus Lat. fo. Ven. 1586 Galeni Oper. Lat. Ven. 1586 Vol. 1 m [-5m] - Libri Medici G.1.1[-5]

6. Pausanias Grae. fo. Franc. 1583

Pausania Descript. Gracia Gr. et Lat. cum Annot. Gr. Xylandri. Fran. $1583-$ Libri Artium P.6.3

7. Rondeletius de Piscibus. fol. Lugd. 1554

Gu. Rondeletius de Piscibus Marinis. Lugd. 1554 - Libri Medici R.1.3

8. Stredius de Gent. Roman. fo. Steph. 1569

Ric. Streinnius de Gent. E Famil. Rom. Stemmat. Par. 1559 [sic] - Libri

Artium Q.S.5.6

9. Thesaurus Ciceronis. fo. Par. 1566

Thesaurus Ciceronis. Par. ${ }_{55} 6$ [sic] - Libri Artium T.3.3. 


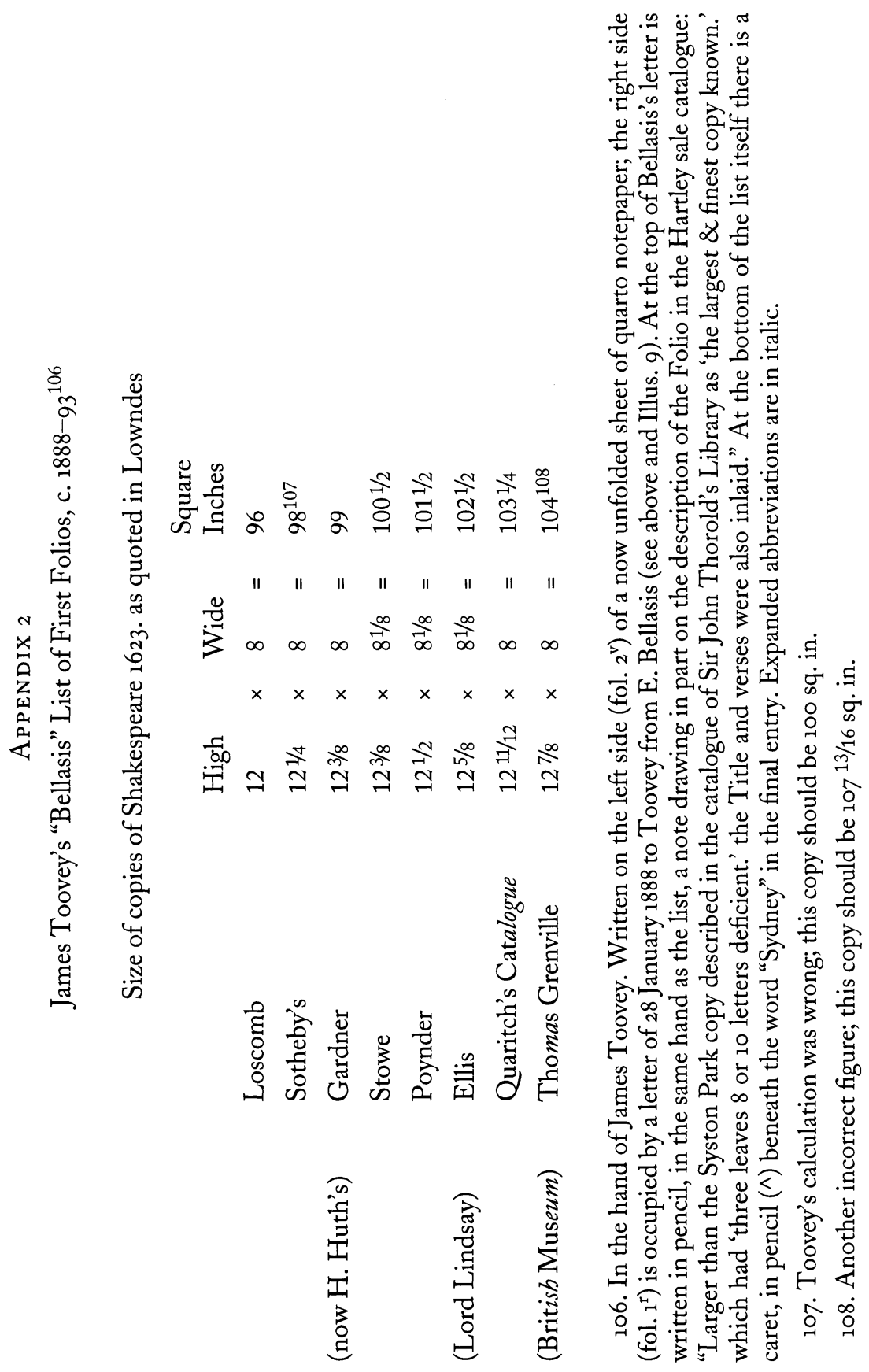



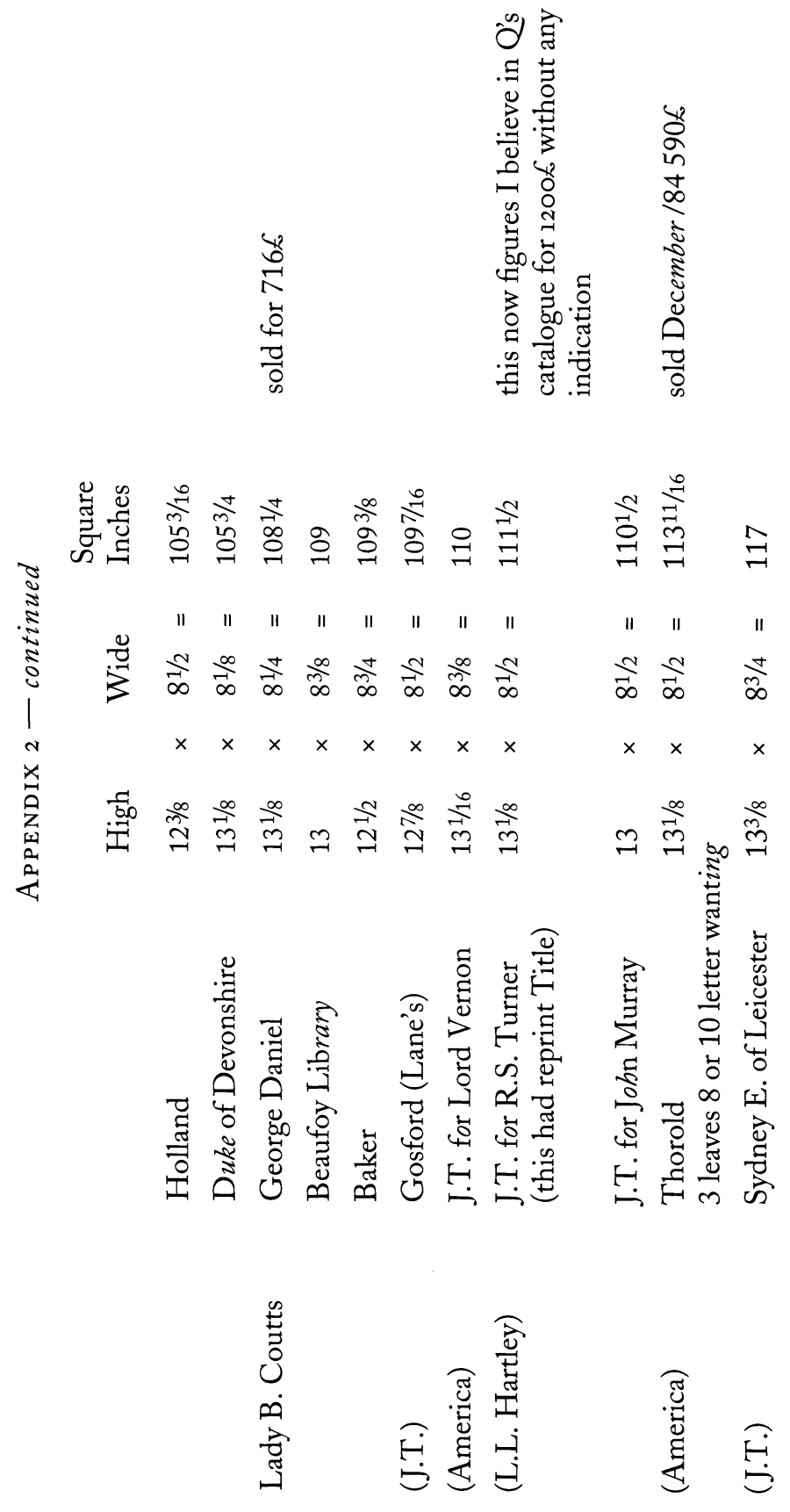